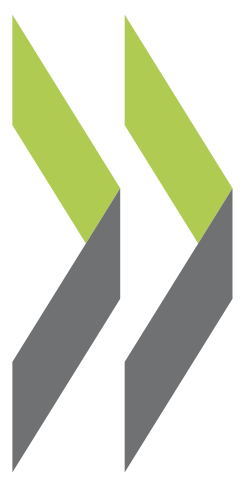

OECD Health Working Papers No. 4

\title{
Survey \\ of Pharmacoeconomic Assessment Activity in Eleven Countries
}

\section{Michael Dickson, Jeremy Hurst,} Stephane Jacobzone 
Survey of Pharmacoeconomic Assessment Activity in Eleven Countries

Michael Dickson, Jeremy Hurst and

Stéphane Jacobzone 
Organisation de Coopération et de Développement Economiques

Organisation for Economic Co-operation and Development

16-May-2003

DIRECTORATE FOR EMPLOYMENT, LABOUR AND SOCIAL AFFAIRS

English - Or. English

EMPLOYMENT, LABOUR AND SOCIAL AFFAIRS COMMITTEE

OECD HEALTH WORKING PAPERS NO. 4

SURVEY OF PHARMACOECONOMIC ASSESSMENT ACTIVITY IN ELEVEN COUNTRIES

Michael Dickson, Jeremy Hurst and Stéphane Jacobzone

JEL Classification: I11

JT00144452

Document complet disponible sur OLIS dans son format d'origine

Complete document available on OLIS in its original format 


\title{
DIRECTORATE FOR EMPLOYMENT, LABOUR AND SOCIAL AFFAIRS
}

\section{OECD HEALTH WORKING PAPERS}

This series is designed to make available to a wider readership health studies prepared for use within the OECD. Authorship is usually collective, but principal writers are named. The papers are generally available only in their original language - English or French - with a summary in the other.

Comment on the series is welcome, and should be sent to the Directorate for Employment, Labour and Social Affairs, 2, rue André-Pascal, 75775 PARIS CEDEX 16, France.

The opinions expressed and arguments employed here are the responsibility of the author(s) and do not necessarily reflect those of the OECD

\section{Applications for permission to reproduce or translate all or part of this material should be made to:}

\author{
Head of Publications Service \\ OECD \\ 2, rue André-Pascal \\ 75775 Paris, CEDEX 16 \\ France
}

Copyright OECD 2003 
DELSA/ELSA/WD/HEA(2003)4

\section{SUMMARY}

1. Policy-makers responsible for publicly-funded drug programmes face continual pressures between the demand to accommodate a steady stream of new and more effective drugs and the ongoing requirement to control costs.

2. In the face of these pressures, a growing number of OECD countries are applying 'pharmacoeconomic assessment' (health technology assessment for drugs) - to new drugs to guide decisions about accepting such products for reimbursement under their public programme, or to inform negotiations about pricing.

3. This paper provides an analytical overview of the developing practice of pharmacoeconomic assessment in eleven OECD countries. It looks at the objectives of the activity, some of its processes and some of its impacts.

4. It does this by drawing on a literature review and on an exploratory survey of the activities of pharmacoeconomic agencies in the eleven countries. It also reviews briefly the state of pharmacoeconomic assessment in the United States.

5. The main conclusions are as follows:

- Judging by the rate at which the formal use of pharmacoeconomic assessment is spreading among OECD member countries, it is proving to be a useful decision-making tool for publicly-funded pharmaceutical benefit schemes as well as for some private insurance plans.

- The most important motive for performing pharmacoeconomic assessments appears to be establishing the value-for-money of new drugs, to inform decisions on reimbursement and/or pricing. It appears to be viewed in some countries as a tool to assess the cost-effectiveness of new drugs against an implicit or explicit benchmark, and in other countries as a tool that can inform the pricing negotiation in a way that pursues cost-effectiveness. The pharmaceutical industry expresses concern that the underlying purpose of assessment is cost-containment and that, as a result, it may stifle innovation. However, there is little evidence from this survey that cost containment is the dominant aim of assessment or that the level or growth rate of drug expenditure has been reduced as a result of pharmacoeconomic assessment activities (although, strictly speaking, the counterfactual is unknown). There could be benefits to society if assessments led eventually to a rise in the quality of (value added by) innovation.

- Pharmacoeconomic assessment is a growing activity, with plenty of room to improve its quality, keeping an eye, of course, on its costs both in terms of research effort and in terms of any additional delay it causes in the marketing of drugs which prove to be cost-effective. There is presumably an optimum amount of pharmacoeconomic assessment - that amount which balances benefits, in terms of improvements in the cost-effectiveness of pharmaceutical consumption, with costs in terms of delays in consumption and discouragement of innovation. But it is extremely difficult to determine this optimum with any precision. 
- There is much interest, among the countries which have been surveyed here, in improved international exchanges of information among national pharmacoeconomic assessment agencies. Presumably it is perceived that there would be potential gains in quality and reductions in the cost of assessments from sharing experience across countries. 
DELSA/ELSA/WD/HEA(2003)4

\section{RÉSUME}

6. Les responsables des programmes et dispositifs assurant la couverture des frais pharmaceutiques à l'aide de fonds publics sont en permanence tiraillés entre une demande de prise en charge d'un flot incessant de médicaments nouveaux et plus efficaces et la nécessité constante d'une maîtrise des dépenses.

7. Face à cette situation, un nombre croissant de pays de l'OCDE ont entrepris de soumettre les nouveaux médicaments à une "évaluation pharmacoéconomique" (évaluation des technologies de la santé appliquée aux médicaments) - pour fonder leur décision de déclarer ou non ces produits remboursables par leur dispositif public ou pour éclairer les négociations sur les prix.

8. Le présent document donne une vue analytique d'ensemble de la pratique d'évaluation pharmacoéconomique, telle qu'elle commence à se développer dans onze pays de l'OCDE; Sont envisagés les objectifs de l'activité, quelques-unes des procédures mises en œuvre et certaines conséquences.

9. Le rapport s'appuie sur une recherche documentaire et sur une enquête relatives aux activités d'évaluation pharmacoéconomique dans onze pays de l'OCDE. Il y est également brièvement rendu compte de l'état de l'évaluation pharmacoéconomique aux Etats-Unis.

10. Les principales conclusions sont les suivantes :

- Le rythme auquel l'utilisation formelle de l'évaluation pharmacoéconomique se répand dans les pays membres de l'OCDE, monter qu'elle constitue un bon outil d'aide à la décision pour les caisses de remboursement des produits pharmaceutiques financées par des fonds publics ainsi que pour certaines caisses privées.

- La principale raison pour laquelle on procède à des évaluations pharmacoéconomiques semble être de déterminer le rapport qualité-prix des nouveaux médicaments, afin d'éclairer les décisions en matière de remboursement et/ou de tarification. Cette évaluation est apparemment considérée, dans certains pays, comme un outil permettant d'apprécier l'efficacité par rapport à leur coût de nouveaux médicaments en fonction de critères implicites ou explicites, et d'autres pays, comme un outil pour étayer une négociation sur les prix dont le mobile serait un bon rapport coût-efficacité. L'industrie pharmaceutique s'inquiète du fait que l'objectif fondamental de l'évaluation soit la maîtrise des dépenses et qu'elle risque d'étouffer l'innovation. Cependant, rien ne prouve dans cette enquête que la maîtrise des coûts soit l'objectif premier de l'évaluation, ni que la dépense totale en médicaments, ou même son taux de croissance, aient été réduits du fait des activités d'évaluation pharmacoéconomique (bien que, à proprement parler, l'on ne sache pas si l'inverse se vérifierait). La collectivité pourrait du reste avoir avantage à ce que l'évaluation permette en définitive d'accroître la qualité de (la valeur ajoutée par) l'innovation.

- L'évaluation pharmacoéconomique est une activité en pleine croissance, dont on a tout le temps d'améliorer la qualité en prenant garde, bien entendu aux coûts qu'elle entraîne, de par l'effort de recherche demandé et également des retards supplémentaires qu'elle cause à la commercialisation des médicaments dont l'utilisation se révélerait rentable. Il existe probablement un niveau optimal d'évaluation pharmacoéconomique, qui assure un équilibre entre les avantages, c'est-à-dire l'amélioration du rapport coût-efficacité de la consommation de produits pharmaceutiques, et les coûts, c'est-à-dire les retards dans la consommation et l'effet dissuasif exercé sur l'innovation. Mais, il est très difficile d'évaluer ce niveau optimal avec précision. 
- Les pays enquêtés ont manifesté un grand intérêt pour une amélioration de la communication entre les organismes d'évaluation pharmacoéconomique nationaux. On peut supposer qu'ils attendent d'un partage des expériences entre pays une amélioration de la qualité des évaluations et un abaissement de leur coût. 


\section{TABLE OF CONTENTS}

SUMMARY

OVERVIEW OF PHARMACOECONOMIC ASSESSMENT LITERATURE ....................................... 10

SURVEY OF PHARMACOECONOMIC ASSESSMENT ACTIVITY IN ELEVEN COUNTRIES ........ 13

Conceptual basis for, and process of, pharmacoeconomic assessment ................................................ 13

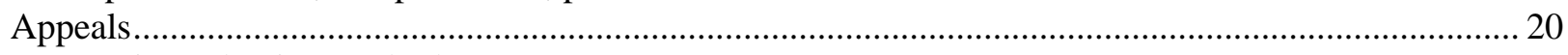

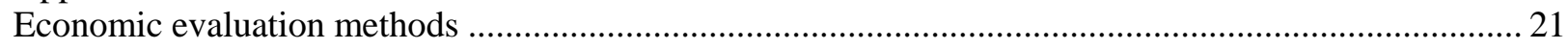

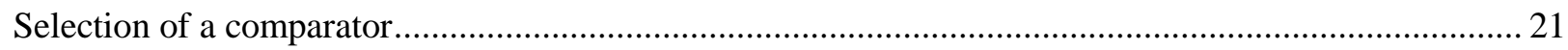

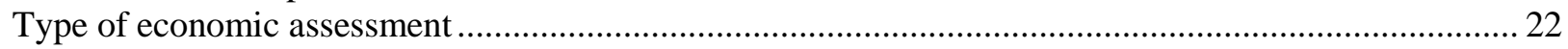

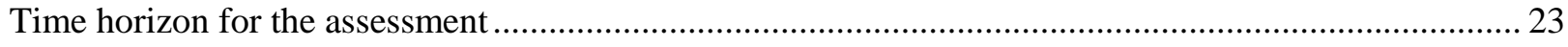

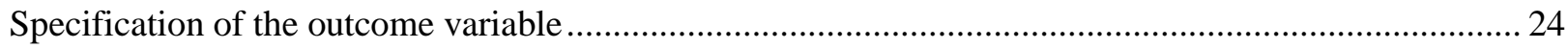

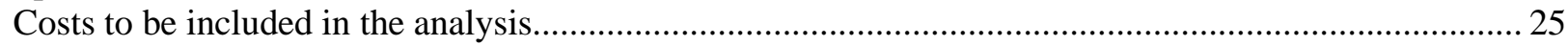

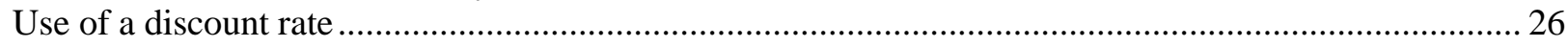

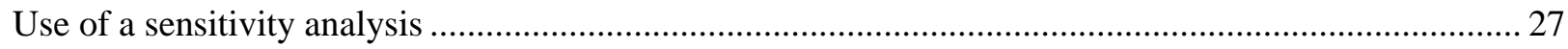

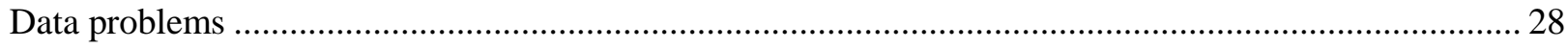

RESULTS FROM PHARMACOECONOMIC ASSESSMENT ……....................................................... 29

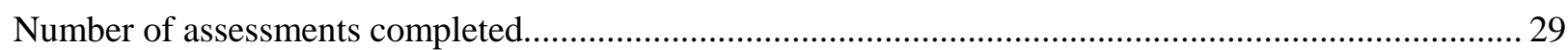

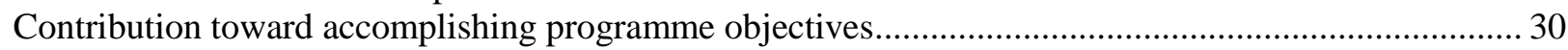

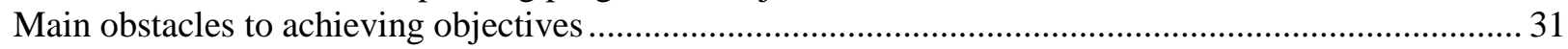

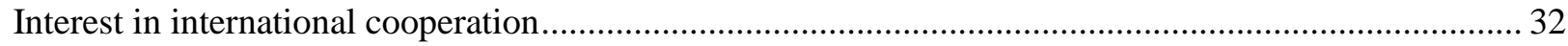

A REVIEW OF PHARMACOECONOMIC ASSESSMENT ACTIVITY IN THE UNITED STATES .... 34

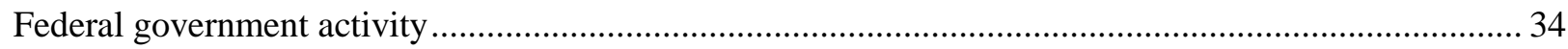

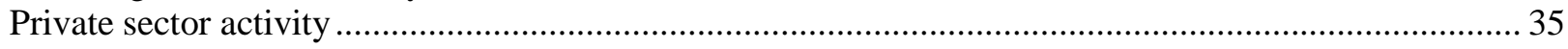

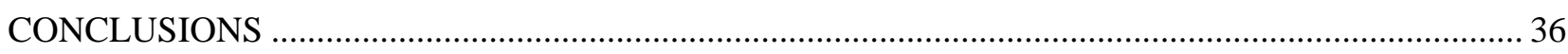

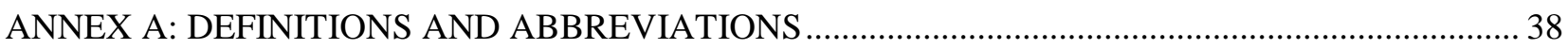

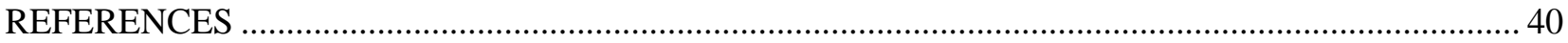




\section{INTRODUCTION}

11. For several decades, there has been tension in publicly-funded drug programmes between the arrival of new, more beneficial, more costly prescription drugs and the ongoing desire for affordability. The ability of public purchasers to control cost and cost-effectiveness has been rather limited because of a combination of factors, including the rapidity of the flow of new drugs and the freedom to prescribe given to physicians under many public drug programmes.

12. As pharmaceutical use has increased substantially in recent years, many third-party payers have turned to pharmacoeconomic assessment to assist them either in determining which products should be purchased under their drug programmes at a given price, or in deciding at what prices they should be purchased, or at what level public reimbursement should be set. Such assessment may also inform the drawing up of guidelines for cost-effective prescribing. Addressing these questions goes beyond the wellestablished practice in all OECD countries of requiring for a drug product that it be shown to be safe and efficacious before it can be marketed for general use. It is a matter of requiring an economic assessment to inform decisions about reimbursement or about pricing. Whereas the procedures for market access and for assessing efficacy have been largely harmonised and coordinated across countries, particularly in Europe, decisions about pricing and reimbursement remain the realm of national policy makers, with a great variability in national arrangements.

13. Pharmacoeconomic assessment is sometimes called the 'fourth hurdle'. That terminology suggests that the drug company will have an additional obstacle to surmount (over and above the normal requirement for the company to demonstrate safety, efficacy and quality for general marketing of the drug) before gaining acceptance of a new product into a public programme.

14. Economic assessment of pharmaceuticals, or 'pharmacoeconomic assessment', can be described as the practice of assessing both the benefits and costs of a pharmaceutical product, or therapeutic class of products, and comparing the two. These assessments are generally commissioned by a government agency. Commonly used methods of assessment include cost-minimisation, cost-effectiveness, cost-utility, and cost-benefit analysis (see Annex A for definitions). Often, the government agency has a benchmark or threshold level of cost-effectiveness in mind (Towse et. al., 2002). It is seeking to approve for reimbursement new drugs whose cost-effectiveness can be shown to exceed the benchmark and to reject for reimbursement new drugs whose cost-effectiveness cannot be shown to exceed the benchmark. Sometimes the cost-effectiveness information is used to inform pricing negotiations for the new drug or the corresponding level of public subsidy.

15. This study has been designed to review the expanding practice of pharmacoeconomic assessment in a sample of OECD member countries. Some of the main questions which were pursued include the following:

- What were the objectives of adopting economic assessment of pharmaceuticals?

- What pharmacoeconomic assessment methods were being used?

- What impacts were observed? 
16. In this study, two main approaches have been taken to answering these questions. First, the literature on the economic analysis of pharmaceuticals was reviewed. Second, an exploratory survey of the activities of pharmaceutical assessment institutions and agencies in a sample of eleven OECD countries was undertaken in 2001, via country representatives at the OECD's Working Party on Social Policy. In addition, a brief review of pharmacoeconomic assessment activities in the United States - where pharmacoeconomic assessment by private insurers is found alongside pharmacoeconomic assessment by public purchasers - was carried out. This paper is written from the perspective of the purchasers of drugs rather than from the perspective of the pharmaceutical industry. It should be regarded as no more than a preliminary assessment and it raises a number of issues which might be covered in greater depth and from a wider perspective on a future occasion. 


\section{OVERVIEW OF PHARMACOECONOMIC ASSESSMENT LITERATURE}

17. Since the early 1990 s, a significant literature has appeared on pharmacoeconomic assessment institutions and methods. This section contains some of the main references which relate to the OECD countries in this study. ${ }^{1}$

18. The formal, organised, and systematic use of pharmacoeconomic assessment by government payers dates from 1993 when Australia was the first country to require pharmaceutical companies (or other product sponsors) to produce economic data, "... in support of applications for listing of new pharmaceutical products on its schedule of pharmaceutical benefits" (Henry, 1992). A set of guidelines for the assessments had been published in 1992. Since these were the first set of formal guidelines to appear there were concerns expressed by the pharmaceutical industry which saw them as, "...yet another mechanism to exert a downward pressure on drug prices in Australia," and by economists who expressed both policy and methodological reservations (Drummond, 1992; Johannesson, 1992; Langley, 1993).

19. A revision of the Australian guidelines was published in November 1995. Langley assessed the revised guidelines as differing in three ways from the original August 1992 version. They required: greater emphasis on detail in the reporting of clinical trial data; a preliminary efficacy-based economic evaluation; and an explicit recognition that the clinical trial data may need to be modeled to achieve estimates of effectiveness. Writing for the Australian Pharmaceutical Manufacturers Association, Grobler echoed the views expressed by Langley and emphasised that the revised guidelines focused on clinical efficacy rather than economic analysis to estimate effectiveness. However, Hailey reported that the Pharmaceutical Benefits Advisory Committee (PBAC) and its advisors considered that the new guidelines were working well and there had been progressive improvements in the quality of submissions from product sponsors.

20. The treatment of indirect benefits (such as the wages gained from earlier return to work by employed people following improved treatment) in the Australian guidelines has been a source of debate between the PBAC, the pharmaceutical industry and some economists since 1993. PBAC's position is that indirect benefits can be included in a submission, if the results are presented both with and without them. Furthermore, the reporting of indirect benefits must be from a societal perspective and must be, "...demonstrated (as with health effects) rather than merely assumed," (Aristides and Mitchell, 1994). This treatment of indirect benefits is likely to continue to be problematic because many new pharmaceutical products will probably claim indirect cost reduction as a significant part of their economic advantage

21. Soon after the introduction of the Australian guidelines, the province of Ontario, Canada adopted pharmacoeconomic guidelines and this was followed by preparation of draft guidelines for Canada as a whole (Detsky, 1993). New Zealand also published pharmacoeconomic guidelines about the same time (Pharmaceutical Management Agency Limited, 1993). While there are similarities between the Canadian, New Zealand, and Australian guidelines, there also are important differences. In 1999 Drummond and colleagues reported that five additional countries (Denmark, Finland, the Netherlands, Portugal, and the UK) required or might require in the future that economic studies be done to obtain reimbursement for

1. The literature on basic economic assessment methods and pharmaceutical pricing/reimbursement policies has not been reviewed for this study. For pricing and reimbursement policies see Jacobzone (2000). 
pharmaceutical products. In addition, France and Spain were exploring the adoption of a formal requirement in 1999. In France, pharmacoeconomic studies are used to inform pricing decisions rather than to choose among alternative therapies. Meanwhile, the Collège des Economistes de la Santé has published a set of guidelines developed by a commission of academic health economists that contains 34 recommendations for the appropriate conduct of pharmacoeconomic evaluations. ${ }^{2}$ In addition to these formal requirements, some countries were moving in this direction by endorsing economic evidence or suggesting that it would be considered in certain cases (Italy, Spain, Germany, and Switzerland). For this review, the important point to note is the rapid adoption of the pharmacoeconomic assessment practices in the early 1990s.

22. The Japanese situation is that the government has moved from no requirements for pharmacoeconomic data prior to 1992, to using it for "reference" purposes, and finally in 1994 companies were required to submit pharmacoeconomic data (Hisashige, 1997).

23. Drummond (1994a) observed that economic evaluation is used for three primary purposes:

- as a basis for pricing and reimbursement decisions,

- as a form of cost containment, and

- as a means of securing value-for-money.

24. If the assessment is used for pricing decisions it is likely to form only a new starting point for price negotiations. Cost containment is unlikely to be the objective if more direct and effective means to that end are in place, such as budget caps or global budgets. If securing value-for-money is the objective, it will be necessary to define the patient population for whom the drug appears to be cost-effective. However, defining patient populations and limiting drug use to such specified groups is difficult at best.

25. In 1995 Jacobs, et. al. compared pharmacoeconomic guidelines under four jurisdictions. The authors contrasted economic assessment methods in Australia, Canada (federal guidelines), Ontario, Canada, and the UK (England and Wales). They noted several differences and contrasted the state of existing guidelines with Generally Accepted Accounting Principles (GAAP), where many of the methods have been standardised. The authors suggest that standardisation of pharmacoeconomic methods is both desirable and possible by establishing a common check list and specifying preferred approaches (e.g., in relation to discount rates, etc.). Drummond also offered advice on how to improve economic analysis of prescription drugs by noting first that different stakeholders have different interests, but there is a common interest in the development of methodological standards (Drummond, 1994b). One attempt, among several, at standardising methods was sponsored by the US Public Health Service (Siegel, et. al., 1997). However commendable this effort might be, it developed little interest because the US does not have a national prescription drug benefit programme. ${ }^{3}$

26. There are those that oppose setting methodological and procedural standards for conducting pharmacoeconomic assessments because they regard the discipline as still in a developing stage during which setting standards would be harmful or counter-productive. This view is somewhat supported by the

2. «Recommandations de bonnes pratiques des méthodes d'évaluation économique des stratégiques thérapeutices. » The recommendations were developed by a commission including academic and pharmaceutical industry representation. The guidelines were initially published in the Journal d'Economie Medicale and are available on the Collège des Economistes de la Santé website at www.perso.wanadoo.fr/ces/pages/guideliln.htm.

3. Except for Medicaid programmes which are operated by the individual states using federal matching funds. 
findings of Mullins and Ogilvie (1998) in which the authors identified a set of common features across pharmacoeconomic assessment guidelines, but a lack of consistency across guidelines in how to implement them. There has been an attempt to harmonise pharmacoeconomic assessment practices in Europe by an ad hoc committee of the International Society for Pharmacoeconomics and Outcomes Research (ISPOR). They reported in 1999 that, "...a significant part of future development in this field lies in integration of standardised health economic data into evidence-based guidelines, which they believed to be an important potential decision-making tool in the future" (Goetghebeur and Rindress, 1999).

27. A 1999 study of trends in pharmacoeconomic research in Europe reported on the activities in 13 European countries (Drummond, 1999). This article provides a valuable summary of how pharmacoeconomic research was being used in the reporting countries at the end of the 1990s. The authors report that the most frequent use was for reimbursement decisions and the least common use was for price negotiations. Other uses included formulary decisions, development of clinical practice guidelines, and communication with prescribers. This contrasts with the situation in 1993 when Drummond, et. al. reported that, "...no European jurisdiction formally required economic evaluation as a basis for pricing and reimbursement decisions".

28. There is a concern that pharmacoeconomic data on a product, generated by the same company that produces the product has the potential for bias. In response to this Hillman (1991) and others have suggested guidelines to make company-generated, pharmacoeconomic data more transparent. Evidence of the need for caution was recently presented in a study by Friedberg and colleagues in which they found no bias in pharmaceutical industry sponsored drug studies, but did find a reduced likelihood that unfavourable results would be reported.

29. In summary, several countries have now adopted some type of formal economic evaluation of pharmaceuticals for a variety of policy purposes and others are making informal use of economic assessments of pharmaceuticals. There have been attempts to standardise pharmacoeconomic reporting, but currently there is a division over whether this is premature or overdue. Finally, there is disagreement on the proper role of pharmacoeconomic data in payer decision making. All uses would seem to have limitations, but payers must solve budget problems now rather than waiting for the perfect solution. The current study was implemented to provide a wider assessment of recent development in the application of pharmacoeconomics in OECD countries and to address some of the unresolved issues identified above. 


\section{SURVEY OF PHARMACOECONOMIC ASSESSMENT ACTIVITY IN ELEVEN COUNTRIES}

30. In February 2001 a questionnaire on economic assessment of pharmaceuticals was distributed to a group of OECD member countries. This report is based on responses received from eleven countries. ${ }^{4}$ The questionnaire asked for responses on each of the following three aspects of pharmacoeconomic evaluations:

- The conceptual basis for the use of pharmacoeconomic assessments

- Economic assessment methods used to evaluate pharmaceuticals

- The results of the assessments

31. This section presents the results of the survey for eleven countries. As the US case was very specific, given multiple payers across the public and private sectors, it is analysed separately in a following section.

\section{Conceptual basis for, and process of, pharmacoeconomic assessment}

32. The first part of the survey explored international differences in the conceptual basis for assessments and various aspects of the process for preparing them.

\section{Conceptual basis for pharmacoeconomic assessment}

33. Five of the ten countries responding to this question reported that their conceptual basis for pharmacoeconomic assessment was "value-for-money" (see Table 1).

4. The number of countries took into account feasibility constraints, given the limited human resources and the time constraints which were imposed on this project. Not all of the eleven countries answered all of the questions. 


\section{In each table an ' $X$ ' is used to indicate a response to a question. In some cases these responses are amplified by notes that are indicated in parentheses at the appropriate place in the table.}

\begin{tabular}{|l|c|c|c|c|}
\hline \multicolumn{5}{|c|}{ Table 1: What is the primary conceptual basis for pharmacoeconomic assessment? } \\
\hline \multicolumn{1}{|c|}{ Country } & $\begin{array}{c}\text { Cost } \\
\text { Containment }\end{array}$ & $\begin{array}{c}\text { Value-for- } \\
\text { money }\end{array}$ & $\begin{array}{c}\text { Global } \\
\text { Budgeting }\end{array}$ & Other \\
\hline Australia & & $\mathrm{X}$ & & $\mathrm{X}$ \\
\hline Belgium & $\mathrm{X}(\mathrm{a})$ & & & Not specified. \\
\hline Canada & & & & $\mathrm{X}(\mathrm{d})$ \\
\hline France & $\mathrm{X}$ & & & \\
\hline Italy & & & $\mathrm{X}$ & \\
\hline Japan & $\mathrm{X}$ & $\mathrm{X}$ & $\mathrm{X}$ & \\
\hline The Netherlands & & $\mathrm{X}$ & & $\mathrm{X}(\mathrm{e})$ \\
\hline Portugal & & $\mathrm{X}$ & & $\begin{array}{c}\text { clinical and cost- } \\
\text { effectiveness }\end{array}$ \\
\hline Sweden & & & & \\
\hline Switzerland & & & & \\
\hline UK & & & & \\
\hline
\end{tabular}

a Currently, pharmacoeconomic evaluations are very limited. In principle, the process consists of evaluating new product cost per mg and by dosage form per day. This occurs when the product sponsor makes a specific request for listing a product for reimbursement. Cost of the new product is compared to that of existing alternatives. The new product may not have a cost of treatment greater than the level of products already reimbursed for the same condition except if it provides a therapeutic gain. This latter aspect is one of the elements in setting a price (the pricing decision). The reason for this decision is not published in the official publication.

b. For 2001, and for the first time, the global budget of pharmaceutical specialties will be fixed in advance by the Minister of Social Affairs. The fixed amount will be published in an official publication (Moniteur Belge).

c. May differ by province.

d. Prices are based on the cost-per-day.

e. Used selectively to inform pricing decisions for new products expected to have a significant market share.

34. Three reported that the basis was cost containment and three that the basis was global budgeting. The Netherlands indicated that all three choices were the basis for their actions. Belgium reported that "cost containment" and "global budgeting" were the reasons for their economic assessments and Italy listed only cost containment. France and Japan both indicated they had reasons other than the specific options provided. In both cases their written comments suggested that assessments were used to establish prices.

\section{Group responsible for conducting pharmacoeconomic assessments}

35. Not surprisingly, the entities responsible for conducting economic analysis of pharmaceuticals are government bodies. However, there are some differences as to where the group resides within the government, the staffing available to conduct the work, and the method by which the chief administrator is chosen. Table 2 summarises key facts about the government entities responsible for pharmacoeconomic assessment. It shows there is wide variation in staffing levels (reported figures range from 5 to 23 FullTime Employees (FTEs)), and that among those countries providing information, the chief administrator was chosen exclusively by the Health Department one-half of the time and by some other arrangement for the other half of countries. However, this a complex issue not easily captured in our survey. 
DELSA/ELSA/WD/HEA(2003)4

\begin{tabular}{|l|l|c|c|c|}
\hline \multicolumn{6}{|c|}{ Table 2: Government entity responsible for processing or conducting pharmacoeconomic } \\
assessments and the number of full-time staff
\end{tabular}

a There is a federal agency and there are also provincial agencies, because prescriptions are paid for by the provincial governments with cost sharing by the federal government. The federal agency does not make decisions on pricing and reimbursement.

b. The group on pharmacoeconomic activity is appointed by the Director General of the Drug assessment agency (AFSSAPS) and the head of the Economic Committee on health products (CEPS). Both of these directors are themselves appointed by the Ministry of Health.

c. The number of additional staff required for pharmacoeconomic assessment activities evaluations will be adapted according to the estimated need.

d. In Switzerland, the government body does not conduct pharmacoeconomic studies on its own. In some cases it may ask a pharmaceutical firm seeking reimbursement to submit independent studies. In other cases the pharmaceutical company may provide their own studies. See Table 3.

36. Among the respondents only Canada reported that assessments were conducted both at the federal and provincial levels. There were responses from five Canadian provinces and two of these reported that they used the Canadian Coordinating Office for Health Technology Assessment (CCOTHA), a federal agency with the mission of encouraging, "...the appropriate use of health technology by influencing decision makers through the collection, analysis, creation, and dissemination of information concerning the effectiveness and cost of technology and its impact on health." agency responsible for economic assessment activities, but this agency does not make decisions on subsidies for prescription drugs because these programmes are operated by provincial governments. The remaining three provincial respondents indicated they made economic assessments of pharmaceuticals and that value-for-money was the objective for their work. Because of variations in assessment procedures across its Provinces, Canada has been omitted from the remaining tables in this paper.

\section{Use of non-governmental consultants}

37. All countries, except Sweden and Italy reported using external consultants for processing or conducting pharmacoeconomic assessments (see Table 3). To avoid potential conflicts of interest, Australia appoints only consultants with no pharmaceutical industry links, and no links to the product sponsors. In France, the expert group reviewing the results are required to have no links to the pharmaceutical industry. Belgium appoints only consultants with no pharmaceutical industry links. The Netherlands, Portugal, and Switzerland appoint consultants with no links to the product sponsor and require that any pharmaceutical industry links be disclosed. The UK merely requires that pharmaceutical industry links be disclosed. Japan reports that when they evaluate a drug price, they check whether the

5. See the CCOHTA website at www.ccohta.ca. 
external consultants have links to the pharmaceutical company of the drug concerned and then do not allow this consultant to participate in a vote on decisions regarding this product.

\begin{tabular}{|l|c|c|c|}
\hline \multicolumn{5}{|c|}{ Table 3: Use of external (non-governmental) consultants and procedures to avoid potential } \\
conflicts of interest \\
\hline Country & $\begin{array}{l}\text { Appoint Consultants w/ } \\
\text { no pharma links }\end{array}$ & $\begin{array}{l}\text { Appoint Consultants w/ } \\
\text { no links to the sponsor }\end{array}$ & $\begin{array}{c}\text { RequirePharma } \\
\text { industry links be } \\
\text { Disclosed }\end{array}$ \\
\hline Australia & $\mathrm{X}$ & $\mathrm{X}$ & $\mathrm{X}$ \\
\hline Belgium & $\mathrm{X}(\mathrm{a})$ & $\mathrm{X}$ & \\
\hline France & $\mathrm{X}$ & & $\mathrm{X}$ \\
\hline Italy (b) & & $\mathrm{X}$ & $\mathrm{X}$ \\
\hline Japan (c) & & $\mathrm{X}$ & $\mathrm{X}$ \\
\hline The Netherlands & & $\mathrm{X}(\mathrm{d})$ & $\mathrm{X}$ \\
\hline Portugal & & & $\mathrm{d}$ \\
\hline Sweden (b) & & & \\
\hline Switzerland & & & \\
\hline UK & & & \\
\hline
\end{tabular}

a. The expert members of the CTSP provide scientists, academics, physician representatives, pharmacists, and representatives of the insurers. The work groups are equally constituted with experts from the academic community.

b. Italy and Sweden do not use expert consultants

c. When they evaluate a drug price they check whether experts have links to the sponsoring pharmaceutical company. Consultants are not allowed to vote on the question.

d. The government agency may require the pharmaceutical firm to appoint external experts to review a product dossier. In these cases, the external consultant should have no links to the product sponsor. Any links to the pharmaceutical industry should be disclosed.

38. The role of external consultants varies across the countries but does not appear to be related to staff size. For example, Australia reports a staff of 14 FTEs and actively uses consultants to assess submissions by product sponsors. The use of consultants appears to be more related to the type of assessment programme operated. In some instances, consultants are actively engaged in preparing the assessment report (e.g., Australia), while in other countries the consultant's role is to advise only on specific technical matters.

\section{Responsibility for preparing the initial assessment}

39. Table 4 shows that for all countries except Japan and the UK, the initial pharmacoeconomic assessment is prepared by the product sponsor (e.g., the manufacturer). In Japan and the UK, product sponsors may submit information to the government agency and it will be considered, but preparation of the economic assessment is the payer's responsibility. Currently in Belgium the product sponsor is responsible for submitting the initial assessment, however, this will change in 2002 when responsibility shifts to the government agency. 


\begin{tabular}{|c|c|c|c|}
\hline \multicolumn{4}{|c|}{$\begin{array}{c}\text { Table 4: Responsibility for doing the initial pharmacoeconomic assessment of a } \\
\text { product }\end{array}$} \\
\hline Country & $\begin{array}{l}\text { Submitted by } \\
\text { Product Sponsor }\end{array}$ & $\begin{array}{l}\text { Prepared by the } \\
\text { Payer }\end{array}$ & Other \\
\hline Australia & $\mathrm{X}$ & & \\
\hline Belgium & $X(a)$ & $X(b)$ & \\
\hline France & $X$ & & \\
\hline Italy & $X$ & & \\
\hline Japan & & $\mathrm{X}(\mathrm{c})$ & \\
\hline The Netherlands & $\mathrm{X}$ & & \\
\hline Portugal & $X$ & & \\
\hline Sweden & $X$ & & \\
\hline Switzerland & $X$ & & \\
\hline UK & & $\mathrm{X}(\mathrm{d})$ & \\
\hline
\end{tabular}

a. Until 2002, a company may propose an evaluation. Beginning in 2002 the evaluation will be done by the government.

b. It is possible that the CTSP external experts or the government administration may do the evaluation.

c. Product sponsors also may express their views regarding an assessment.

d. Product sponsors are invited to submit evidence or assessments. The body commissioned to carry out the evaluation report considers these along with other evidence.

40. The practice of allowing sponsor companies to prepare the initial assessment presents the possibility of them selectively presenting material and adopting a format that is favourable to the product under consideration. To ensure that information important to government payers is adequately presented, some governments have adopted guidelines for submissions or have specified that certain data must be included. These specifications are presented later in the report.

\section{Method of selecting products for economic analysis}

41. In all countries there must be some method by which products are selected for economic assessment since it would be virtually impossible and wasteful to make these assessments on all marketed products. Of the countries reporting, virtually all make analyses for newly marketed products at the time of marketing approval, or very soon after approval has been granted (see Table 5). However, the method of selecting new products is quite variable across countries. Australia and Belgium make pharmacoeconomic assessments for all new products. Italy does assessments only for new "European" drugs. The Netherlands reviews only those products that cannot be placed in a group of therapeutically interchangeable products in their Reference Price System (GVS), a decision that is made by a committee of experts of the Health Insurance Board. In Portugal, pharmacoeconomic assessment is made only for products submitted spontaneously by the pharmaceutical industry. Sweden selects products where there are strong reasons for doing this, for example, for innovative products, and for products where it is difficult to find a comparator. The UK is the only country where pharmacoeconomic assessments are made by an Agency, the National Institute for Clinical Excellence (NICE), for new products selected by government officials and Japan is the only country where new products are selected by an individual of the government agency responsible for the assessments. 


\begin{tabular}{|l|c|c|c|c|c|}
\hline \multicolumn{7}{|c|}{ Table 5: Method for selecting new product for pharmacoeconomic assessment } \\
\hline \multicolumn{1}{|c|}{ Country } & $\begin{array}{c}\text { New products in } \\
\text { selected } \\
\text { therapeutic } \\
\text { categories }\end{array}$ & $\begin{array}{c}\text { New products } \\
\text { selected by a } \\
\text { government body }\end{array}$ & $\begin{array}{c}\text { New products } \\
\text { selected by an } \\
\text { individual } \\
\text { govt. official }\end{array}$ & Other \\
\hline Australia & $\mathrm{X}$ & & & & \\
\hline Belgium & $\mathrm{X}$ & & & & $\mathrm{X}$ \\
\hline France & & & & & $\mathrm{X}$ \\
\hline Italy & & & & & $\mathrm{X}$ \\
\hline Japan & & & & & $\mathrm{X}$ \\
\hline The Netherlands & & & & & $\mathrm{X}$ \\
\hline Portugal & & & $\mathrm{X}(\mathrm{b})$ & & \\
\hline Sweden & & & $\mathrm{X}$ & & \\
\hline Switzerland & & & & & \\
\hline UK (c) & & & & & \\
\hline
\end{tabular}

a. Products are selected by the firms.

b. The Federal Office for Social Security in Switzerland may request pharmacoeconomic studies from the pharmaceutical company if the new product is expected to have a significant market share. This information is used to help establish a price for the product by taking into account innovation expenditure. A similar strategy is used when it is difficult to find a comparator product.

c. NICE does not make pricing or reimbursement decisions.

42. Some countries also have procedures for selecting already marketed products for pharmacoeconomic analysis while others do not include existing products in their assessments. Approaches to pharmacoeconomic assessment of existing products reported by respondents are shown in Table 6 . For Australia, Belgium, Italy, Sweden and Japan, pharmacoeconomic assessments are not made for products already on the market. In the Netherlands, products already on the reimbursement list are not selected for pharmacoeconomic analysis. In Portugal, products already on the market are selected by a committee or submitted spontaneously by the pharmaceutical industry for pharmacoeconomic analysis. In the UK, products already on the market are selected by the same method as newly marketed products. 


\begin{tabular}{|c|c|c|c|c|c|}
\hline \multicolumn{6}{|c|}{ Table 6: Method for selecting products already on the market for pharmacoeconomic assessmen } \\
\hline Country & $\begin{array}{l}\text { Economic } \\
\text { assessments } \\
\text { are not } \\
\text { made for } \\
\text { products } \\
\text { already on } \\
\text { the market }\end{array}$ & $\begin{array}{l}\text { Products } \\
\text { already on the } \\
\text { market in } \\
\text { selected } \\
\text { therapeutic } \\
\text { categories }\end{array}$ & $\begin{array}{l}\text { Products already } \\
\text { on the market } \\
\text { selected by a } \\
\text { government } \\
\text { committee }\end{array}$ & $\begin{array}{l}\text { Products already } \\
\text { on the market } \\
\text { selected by an } \\
\text { individual } \\
\text { government. } \\
\text { official }\end{array}$ & Other \\
\hline Australia & $\mathrm{X}(\mathrm{a})$ & & & & \\
\hline Belgium & $\mathrm{X}(\mathrm{b})$ & & & & \\
\hline France & & & & & $\mathrm{X}(\mathrm{c})$ \\
\hline Italy & $\mathrm{X}$ & & & & \\
\hline Japan & $\mathrm{X}$ & & & & \\
\hline The Netherlands & & & & & $\mathrm{X}$ \\
\hline Portugal & & & $\mathrm{X}$ & & $\mathrm{X}$ \\
\hline Sweden & $\mathrm{X}$ & & & & \\
\hline \multicolumn{6}{|l|}{ Switzerland } \\
\hline UK & & & & & $\mathrm{X}$ \\
\hline
\end{tabular}

a. On occasion, a review of one or more products has been conducted on the recommendation of the PBAC or the Government. More frequently, product sponsors request changes to the subsidy status of products already on the market which requires that the product be given an economic assessment.

b. Except when a request is made for a change in the conditions of reimbursement for a product.

c. Selected by the firms.

\section{Procedure for reviewing previous assessments}

43. Respondents were asked if they had policies on reviewing their previous assessments (see Table 7). Seven out of the eight countries reporting well-established processes do not have a procedure for reviewing past assessments. The exception is the UK. The Netherlands and Portugal are considering whether to review past economic assessments in future.

\begin{tabular}{|c|c|c|}
\hline \multicolumn{3}{|c|}{$\begin{array}{c}\text { Table 7: Is there a procedure for reviewing previou } \\
\text { pharmacoeconomic assessments? }\end{array}$} \\
\hline Country & Yes & No \\
\hline Australia & & $\mathrm{X}$ \\
\hline Belgium & & $\mathrm{X}$ \\
\hline France & & $X$ \\
\hline Italy & & $\mathrm{X}$ \\
\hline Japan & & $\mathrm{X}$ \\
\hline \multicolumn{3}{|l|}{ The Netherlands (a) } \\
\hline Portugal (b) & & \\
\hline Sweden & & $\mathrm{X}$ \\
\hline Switzerland & & $X$ \\
\hline UK & $\mathrm{X}$ & \\
\hline
\end{tabular}

a At the time of the survey it had been decided that products for which cost-effectiveness had been claimed would be included in the reimbursed package if such cost-effectiveness had been demonstrated by a pharmacoeconomic analysis. Consideration was being given to whether it was possible to demand further outcomes studies, in case the Board had any doubts about the assumptions made in the analysis or the external validity of the analysis.

b. At the time of the survey, the procedure was not yet established. However, observation and evaluation of some products, in terms of comparative efficacy had begun that included products that had been previously assessed. 


\section{Appeals}

44. Some countries have a procedure by which a product sponsor can appeal a government's assessment decision they regard as adverse (see Table 8). In other countries it is not possible to appeal the pharmacoeconomic assessment directly, but there is a possibility to appeal the reimbursement decision. In Italy, the product sponsors go through a negotiation process with the government body that gave the decision. Portugal does not have an appeal process, per se, but the product sponsor can make a new submission if they have new clinical or pharmacotherapeutical evidence that could change the previous judgement. Sweden has a three-tier process for appealing a pharmacoeconomic assessment decision. First an appeal is made to a local court of appeal, the Länsrätten. Then a decision by the Länsrätten can be appealed to the national court of appeal, the Kammarrätten, and this in turn can be taken to the Supreme Administrative Court, the Regeringsrätten. The UK has a process by which a product manufacturer, or other interested parties, have ten days in which to lodge an appeal against a National Institute of Clinical Excellence (NICE) recommendation. The appeal must be made on one of the following three grounds: 1) a perverse exercise of judgement ("Wednesbury unreasonableness"), 2) an irregularity in the process, or 3) that NICE exceeded its legal powers. The Chairman of NICE then decides whether prima facie grounds for an appeal exist, and if so, an appeal panel of NICE and independent representatives (including one from the relevant industry) is created for a review. If the appeal is upheld the issue is referred back to NICE's appraisals committee. Japan also has a process by which product sponsors can appeal adverse decisions.

\begin{tabular}{|l|c|c|}
\hline \multicolumn{3}{|c|}{ Table 8: Process by which product sponsors can appeal a decision by } \\
the government entity
\end{tabular}

a. Question is not relevant to the French situation because the Pharmacoeconomic Assessment Group can only give advice, and does not take decisions. Decisions are taken by the CEPS for reimbursement purposes. In theory, any decision taken by a public authority can be challenged in public courts.

b. In Italy, an appeal is made in the negotiation process.

c. Since a pharmacoeconomic study is not required, there is no appeal process. However, the pharmaceutical firm may appeal the price set by the Federal Office of Social Security.

d. There is no appeal against the Department not submitting a technology to NICE for appraisal. However, it is possible to appeal against a recommendation from NICE.

45. Australia, Belgium, and the Netherlands do not have an official appeal process. However in Australia, sponsors may re-submit applications requesting listing of a pharmaceutical product. They may also seek a court review of the process followed by the PBAC in reaching a decision. The court cannot make a new decision on the issue, but it can ask the PBAC to correct identified errors in the process and then re-make the decision. 


\section{Economic evaluation methods}

46. The survey explored variations in the methods used by countries to carry out the economic evaluations. Variations in methods were explored under seven headings.

- selection of a comparator

- type of economic assessment

- time horizon for the assessment

- specification of the outcome variable

- costs to be included in the analysis

- use of a discount rate

- use of a sensitivity analysis

\section{Selection of a comparator}

47. Pharmacoeconomic assessments are virtually always comparative, whether the product in question is compared with some specified standard of performance or with other products and treatments. If an existing treatment (e.g., another pharmaceutical or some procedure, such as surgery) is to be used for comparison in the economic assessment, then selection of this alternative treatment is of paramount importance in determining the outcome from the assessment. Table 9 presents how respondents select a comparator for their pharmacoeconomic assessments.

\begin{tabular}{|l|c|c|c|c|c|c|}
\hline \multicolumn{7}{|c|}{ Table 9: How is the comparator for pharmacoeconomic assessment selected? } \\
\hline \multirow{4}{*}{ Country } & \multicolumn{2}{|c|}{$\begin{array}{c}\text { Specified by the } \\
\text { assessment body }\end{array}$} & \multicolumn{2}{c|}{$\begin{array}{c}\text { Selected by the } \\
\text { product sponsor }\end{array}$} & \multicolumn{2}{c|}{ Other } \\
\cline { 2 - 8 } & Yes & No & Yes & No & Yes & No \\
\hline Australia & & $\mathrm{X}$ & & $\mathrm{X}$ & $\mathrm{X}(\mathrm{a})$ & \\
\hline Belgium & & & & & & \\
\hline France & & & $\mathrm{X}$ & & $\mathrm{X}(\mathrm{b})$ & \\
\hline Italy & $\mathrm{X}$ & & & $\mathrm{X}$ & & $\mathrm{X}$ \\
\hline Japan & $\mathrm{X}$ & & & $\mathrm{X}$ & & $\mathrm{X}$ \\
\hline The Netherlands (c) & $\mathrm{X}$ & & $\mathrm{X}$ & & & \\
\hline Portugal & & $\mathrm{X}$ & $\mathrm{X}$ & & & $\mathrm{X}$ \\
\hline Sweden & & & & & $\mathrm{X}$ & \\
\hline Switzerland & & & & & $\mathrm{X}(\mathrm{d})$ & \\
\hline UK & & & & & & \\
\hline
\end{tabular}

a. The sponsor selects the appropriate comparator according to the advice provided the PBAC Guidelines. The PBAC may disagree with the sponsor's choice of comparator. If this occurs then the whole assessment provided by the sponsor may be irrelevant. Note that the selection of comparator is inextricably linked to the indication or purpose specified. Thus the PBAC Guidelines put the question of comparator after the question of the indication.

d. Guidelines are prepared by the French Health Economists Group (Collège des Economistes de la Santé).

c. In general, Dutch guidelines for pharmacoeconomic research are submitted by the Health Insurance Board to the Minister of Health, Welfare and Sport.

d. The comparator is sometimes selected by NICE and sometimes by the product sponsor. Increasingly, the comparator will be specified by DH/NAW in referring topics to NICE. 
48. In Australia, the product sponsor selects an appropriate comparator based on advice given by relevant sections of the PBAC Guidelines. In the Netherlands a comparator is specified by the assessment body. In Portugal and Switzerland the comparator is selected by the product sponsor or in some instances may be specified by the assessment body. Sweden's comparator is selected by the product sponsor. In the UK the comparator is sometimes specified by the assessment body and sometimes selected by the product sponsor. Increasingly, the comparator will be specified by the Department of Health when it refers topics to NICE. In Japan, the comparator is specified by the government assessment body.

49. In most countries the government has some role in determining what comparator will be used in an economic assessment. The assessment agency may select the comparator directly, through the use of guidelines, as in Australia, or it may approve a comparator suggested by the product sponsor. This involvement in selecting a comparator is recognition of the importance of this choice in determining the results of the assessment.

\section{Type of economic assessment}

50. Australia, the Netherlands, and Switzerland do, and Portugal, Japan, and the UK do not, specify the type of economic assessment that must be used (see Table 10).

51. In Australia, there are guidelines that product sponsors must follow in selecting the type of economic assessment to be used in the preparation of the submission. Where the proposed drug has significant clinical advantages over the main comparator, the increase in benefits should be quantified and weighed against any increase in costs. Cost-effectiveness analysis or cost-utility analysis are suitable forms of evaluation in this situation (for an explanation of these terms, please see Annex c). Where the proposed drug is no worse than the comparator in terms of effectiveness and toxicity, the appropriate type of economic evaluation is cost-minimisation analysis. Effectively this means that the proposed drug is unlikely to be granted a higher price than competitors' drugs on the Pharmaceutical Benefit Scheme (PBS) and any restrictions applying to these drugs will apply to the proposed drug. Where the proposed drug is less effective than the main comparator, but is associated with less toxicity, and there are clinical trade-offs as well as cost trade-offs, it is important to include the information on adverse outcomes in the evaluation. In all cases, cost-benefit analysis is discouraged (but not prohibited). 
DELSA/ELSA/WD/HEA(2003)4

\begin{tabular}{|l|c|c|c|}
\hline \multicolumn{5}{|c|}{ Table 10: Type of economic analysis required, how the time horizon is specified, and } \\
specification of the outcome variable
\end{tabular}

a. The PBAC Guidelines recommend what type of economic evaluation should be performed according to the interpretation of clinical data presented (i.e., whether the drug has a clinical advantage, or is therapeutically equivalent or whether it is less effective but also less toxic compared with the comparator).

b. While the PBAC Guidelines do not specify a specific time period, they do indicate that the time horizon should be appropriate for the condition being treated.

c. Only general guidelines from the French Health Economists Group (Collège des Economistes de la Santé).

52. Guidelines for the Netherlands state that a product that has added therapeutic value compared with existing products must include a cost-effectiveness analysis that considers the intended effect of the product and the disorder for which it is intended. A cost-utility analysis is particularly appropriate if there are differences in the quality of life.

53. In Portugal, all the commonly used economic assessment techniques are accepted, however, the preference is for cost-effectiveness and cost-utility analysis. In all cases the selection of a method should be made in accordance with the measurement and evaluation of outcomes to be used.

54. In Switzerland there is no requirement for pharmacoeconomic studies and therefore no guidelines are applied. Instead, there is a cost analysis approach for reimbursable drugs. The new product is compared (normally on a defined daily dose) with drugs in the same therapeutic category in Switzerland. In addition the price is compared with those in four European countries (Denmark, Germany, Holland and Great Britain) as well as in three countries adjacent to Switzerland (France, Austria and Italy).

\section{Time horizon for the assessment}

55. Results from the same economic analysis can be significantly different depending on the time horizon used. For example, the costs and consequences for a drug may be unfavourable at six months, but favourable at one year. Thus, selection of the time horizon can determine the outcome of an economic analysis. Results obtained from asking this question are presented in Table 10.

56. Only the Netherlands specifies time horizons, where the period under analysis must be such that it enables valid and reliable statements to be made. If modelled data are necessary to meet this requirement, then the model's structure and basis need to be described. The model must have a sound scientific basis at the time the study was performed. Japan specifies that all assessments must generate cost-per-day for the alternative treatments. 
57. Australia does not specify a specific time period, however, their Guidelines do indicate that the time horizon should be appropriate for the condition being treated. The Guidelines recognise that the appropriate time horizon for follow-up will vary according to the disease and treatment patterns and an estimation of the time period(s) in which the outcomes are expected to occur from the natural history of the disease. Thus, an explanation and justification for the linking of measured short-term and/or surrogate outcomes to any modeled final outcomes, including a justification for how these are quantified over time, is requested. A definition and justification of the appropriate time horizon for follow-up is also requested. Changes to the existing guidance have been proposed and may be viewed at the following URL: http://www.health.gov.au/haf/docs/pharmpac/interim/index.htm.

\section{Specification of the outcome variable}

58. Economic assessments of pharmaceuticals can, in principle, utilise a variety of health outcome measures. These may be determined by the condition to be treated. However, a common problem is that the data are not readily available. For example, the most appropriate outcome for assessing an antihypertensive agent is likely to be the number of life-years saved. However, hypertension is a chronic disease that often takes years to result in death. It is simply impractical to follow-up the use of antihypertensive agents until the outcome of death is reached, so it is common practice is to use a surrogate outcome, such as blood pressure reduction. The choice of an outcome measure can influence the conclusions of an assessment. The responses on whether an outcome variable is specified are shown in Table 10.

59. Only the Netherlands and Japan indicated that the outcome variable is specified by the government assessment agency. The assessment body in the Netherlands specifies that outcomes from cost-effectiveness analyses should be clearly based on effectiveness (the expected impact in a general patient population) and not efficacy (the impact observed under controlled, experimental conditions)). Efforts should be made to collect information on the relevant end points in terms of morbidity and mortality. If possible, the data should be collected under realistic conditions. If no effectiveness data are available, then appropriate modeling techniques may be used to translate data from efficacy studies into what can be expected in practice (i.e., effectiveness). The model used must have a sound scientific basis. All assumptions in such modeling techniques must be explicitly stated and evaluated with the help of a sensitivity analysis. If cost-utility analysis is used in the Netherlands, survival and quality of life results must be reported separately. The method for combining the two must be clearly described. The recommended method for primary analysis is to combine survival data with the quality-of-life valuation using quality-adjusted life years (QALY's). Utilities must be used as quality-weighting for the calculation of QALY's, measured on an interval scale, where 0 represents the state of death and 1 represents good health. Thus, in the Netherlands, some choice of outcome variable is permitted, but how the outcome variables are to be defined is restricted by the assessment body.

60. In Japan the assessment body specifies only that the all costs are calculated on a cost-per-day basis so that direct comparisons can be made to other agents. In the strictest sense this is not specification of an outcome variable, but it is an attempt to achieve comparability among various treatment alternatives so that comparisons can be made.

61. Australia, Portugal, and the UK do not directly specify an outcome variable. However, Australia has very specific requirements for the way that the outcome variable chosen by the product sponsor is handled. Their Guidelines request that the most scientifically rigorous results for each patient-relevant outcome measured in each trial (or meta-analysis) be presented as the extent of any differences in outcomes between the proposed drug and the main comparator in terms of their natural units. These results become the basis for a preliminary economic evaluation based on these most scientifically rigorous results. 
Frequently it also is necessary to model from these results. Overall, it is preferred that, wherever possible, the outcomes presented include final outcomes such as deaths prevented, life-years gained, or qualityadjusted life-years gained. However, it is acknowledged that, in practice, few trials measure the impact of drug therapy on final outcomes but rather rely on surrogate (intermediate) outcome indicators. Sponsors are therefore encouraged to select those outcome indicators which are most appropriate, and most feasible, given the data available to them. The clinical significance and relevance of the outcome indicators should be established and, if necessary, supported with data. Similarly, any modeling approach should be clearly presented and justified (with a strong steer towards independent verification of all aspects of any computerised modelling).

62. The rationale in Portugal is similar to that described for Australia. The choice of an outcome variable depends on the type of analysis to be conducted and the use of intermediate objectives (rather than the final outcome) is permitted if there are no outcome data available. All the choices of outcome variables must be explained.

63. In most countries, product sponsors have some choice in the specification of the outcome variable. However, in every country the choice must be justified. In more than one instance the government indicates that outcomes must be based on effectiveness data. If these are not available, then the efficacy data must be used to model effectiveness and the modeling must be fully explained and justified.

\section{Costs to be included in the analysis}

64. Governments differ on the type of costs they allow to be included in a pharmacoeconomic assessment. Their specifications about costs are presumably related to the purpose of the analysis and the conceptual basis of the assessment programme. For this study respondents were asked which of three types of costs they would allow to be included: medical direct costs only, all direct costs, and all costs (see Table 11).

\begin{tabular}{|l|c|c|c|c|c|}
\hline \multicolumn{7}{|c|}{ Table 11: What costs are included in an economic analysis? } \\
\hline Country & $\begin{array}{c}\text { Medical direct } \\
\text { costs only }\end{array}$ & All direct costs & All costs & $\begin{array}{c}\text { Opportunity } \\
\text { costs included? }\end{array}$ & Other \\
\hline Australia & Yes & No (a) & No & & \\
\hline Belgium & & & & & \\
\hline France & & & & & X (b) \\
\hline Italy & No & No & No & No & No \\
\hline Japan & No & Yes & No & No & No \\
\hline The Netherlands & No & Yes & Yes & No & \\
\hline Portugal (c) & No & Yes & Yes & Yes & No \\
\hline Sweden & n/a & n/a & n/a & n/a & n/a \\
\hline Switzerland & No & No & No & Yes & Yes (d) \\
\hline UK & & &
\end{tabular}

a. The PBAC Guidelines require an incremental approach, so that the economic evaluation must estimate the changes in costs following the introduction of the proposed drug and divide these costs by the changes in health outcomes.

b. See guidelines from the French Health Economists Group (Collège des Economistes de la Santé).

c. Only indirect costs related to productivity losses should be included. These costs must be reported separately and must be submitted to sensitivity analyses.

n/a Not applicable

d. Direct costs to NHS + Personal Social Services where relevant. 
65. Portugal and Sweden allow all costs to be included in the economic assessment whereas the Netherlands allowed all direct costs, and Australia permitted only medical direct costs. However, Portugal does limit the inclusion of indirect costs to only those that are related to productivity losses. These indirect costs must be reported separately and the results submitted to sensitivity analysis. In the UK only direct costs to the NHS may be included in the cost calculation. The UK also permits inclusion of "Personal Social Services" costs where they are relevant to the condition being treated.

66. In addition to direct medical costs, Australia also permits reporting of direct non-medical and indirect costs. If the product sponsor presents these costs, the economic evaluation should be prepared both with and without these costs. The relative weights of these other types of costs in the decision making process are not specified. In all cases, costs should be valued from the societal perspective (i.e., include contributions to each type of cost from any payer, such as government and the patient). The Australian Guidelines take an incremental approach to the economic assessment which means that the economic evaluation should estimate the changes in costs following the introduction of the proposed drug and divide these costs by the changes in health outcomes.

\section{Use of a discount rate}

67. The use and effects of many drugs extend for years, especially for chronic conditions. In those cases where drug effects and utilisation occur for longer than one year it is regarded as good practice to employ discounting to properly assess the flows of costs and benefits from drug use. Responses to the questions about discounting can be found in Table 12.

\begin{tabular}{|c|c|c|c|c|c|c|}
\hline \multicolumn{7}{|c|}{ Table 12: How is discounting used in an economic analysis? } \\
\hline Country & Not used & $\begin{array}{c}\text { Used in studies } \\
\text { longer than one } \\
\text { year }\end{array}$ & $\begin{array}{l}\text { Payer } \\
\text { sets rate }\end{array}$ & $\begin{array}{l}\text { Sponsor } \\
\text { sets rate }\end{array}$ & $\begin{array}{c}\text { Costs and } \\
\text { benefits use } \\
\text { different rates }\end{array}$ & Other \\
\hline Australia & No & Yes & Yes (a) & Yes & No & \\
\hline Belgium & & & & & & \\
\hline France & & & & & & $\mathrm{X}(\mathrm{b})$ \\
\hline Italy & & & & & & \\
\hline Japan & No & No & No & No & No & \\
\hline The Netherlands & No & No & Yes & No & No & \\
\hline Portugal & No & Yes & Yes & Yes & No & $\mathrm{X}(\mathrm{c})$ \\
\hline Sweden & No & & No & Yes & Yes & \\
\hline Switzerland & $\mathrm{n} / \mathrm{a}$ & & & & & \\
\hline UK & No & Yes & Yes & No & Yes & Yes \\
\hline
\end{tabular}

a. The PBAC Guidelines and an Interim Document note that discounting of future costs and benefits is a standard feature of economic evaluation. The Guidelines recommend that costs and benefits be discounted at an annual rate of $5 \%$. The Guidelines also recommend that, if discounting has been necessary, the robustness of the conclusions to different discount rates (including a zero discount rate on non-monetary outcomes alone and on both costs and outcomes) be tested.

b. See guidelines from the French Health Economists Group (Collège des Economistes de la Santé).

c. All costs and consequences should be discounted at a base rate of $5 \%$. This rate should be varied using sensitivity analysis. If consequences are not monetary valuated, the sensitivity analysis should include the $0 \%$ rate. Other rates could be selected and used by the sponsor with justification.

n/a Not applicable 
68. Five of the seven countries that responded to this question indicated that costs and benefits should be discounted in the economic evaluation. Of these, four indicated that the rate was set by the payer and one that it was set by the product sponsor. Some countries also specified that the discount rate should be varied in the sensitivity analysis. Discounting is one aspect of pharmacoeconomic assessment on which most countries are in agreement.

\section{Use of a sensitivity analysis}

69. The economic assessment of pharmaceuticals is always conducted under conditions of uncertainty about the size of some of the relevant factors and their effect on costs and benefits. That means that assumptions have to be made about some of the components. The typical approach to managing uncertainty in the analysis is the use of sensitivity analysis, either on all the variables that could influence the results or on a subset. Responses to questions on the sensitivity analysis are shown in Table 13. Australia, the Netherlands, Portugal, and Sweden required sensitivity analysis on any variable for which the estimates were imprecise or which represented a key component in the analysis.

\begin{tabular}{|l|c|c|c|}
\hline \multicolumn{4}{|c|}{ Table 13: Is sensitivity analysis required? } \\
\hline Country & $\begin{array}{c}\text { Sensitivity analysis } \\
\text { is not required }\end{array}$ & $\begin{array}{c}\text { Sensitivity analysis is } \\
\text { required for imprecise } \\
\text { estimates only }\end{array}$ & $\begin{array}{c}\text { Sensitivity analysis is } \\
\text { required on key } \\
\text { assumptions only }\end{array}$ \\
\hline Australia & No & Yes & Yes \\
\hline Belgium & & & \\
\hline France (a) & & No & No \\
\hline Italy & No & Yes & Yes \\
\hline Japan & No & Yes & Yes \\
\hline The Netherlands & No & Yes & n/a \\
\hline Portugal & No & n/a & \\
\hline Sweden & n/a & & \\
\hline Switzerland & & & \\
\hline UK (b) & &
\end{tabular}

a. There are no specific requirements. Sensitivity testing on key variables which are subject to uncertainty is expected as good practice.

n/a Not applicable

b. See guidelines from the French Health Economists Group (Collège des Economistes de la Santé).

70. The Australian Guidelines specify that sensitivity analyses should be conducted and a 95\% confidence interval of the health outcome is emphasised as appropriate. The intent is to clarify those components of variables or structure that drive the model and thus to assess the robustness of its results and conclusions. The Guidelines requests that one-way sensitivity analyses be conducted on all variables using extreme values and be presented in tabular form and as a tornado diagram. It also requests that a two-way sensitivity analyses be conducted on all variables shown to be sensitive in the one-way analyses and presented in tabular form and as graphs. The model's results should be compared against any corresponding results obtained empirically and differences commented on. The impact and usefulness of some of these requests is subject to review in the Guidelines revision process. The Australian approach also suggests that it may be helpful to examine the sensitivity of the model to any changes in assumptions concerning the structure of the modeled evaluation which are important but debatable. If discounting has been necessary, the robustness of the conclusions to different discount rates (including a zero discount rate on non-monetary outcomes alone and on both costs and outcomes) be tested. 
71. In the Netherlands a sensitivity analysis must be used to show how the results depend on the assumptions made. As a minimum, a univariate sensitivity analysis must be included. If this is insufficient, then multivariate techniques must be used. The methods used, the choice of the parameters and the range of these parameters all need to be stated and substantiated.

72. Portugal requires that sensitivity analysis of results for different values of key-parameters be stochastically estimated. Whenever estimates are obtained by means of sampling, this analysis should be based on the confidence intervals calculated for each variable. In other cases the choice of ranges or of alternative values for the parameters should be justified in detail on the basis of empirical evidence or logic.

73. Most countries require some form of sensitivity analysis to test the robustness of the findings. This merely reflects the difficulties of conducting economic assessments of pharmaceuticals.

\section{Data problems}

74. The earlier discussion reveals in most cases the initial economic assessment of a pharmaceutical product is made by the product sponsor. This approach and the analytical challenges in general raises the possibility of problems with the data used in the assessment. Study participants were asked about any difficulties with data they had encountered in conducting economic assessments. These results are presented in Table 14. Several respondents indicated that the data they received was incomplete or lacked transparency. Most respondents stated the data were poorly presented. Less than half of the respondents suggested there were errors in the data and an equally small proportion stated that product sponsors failed to follow specified guidelines for reporting.

\begin{tabular}{|c|c|c|c|c|c|c|}
\hline \multicolumn{7}{|c|}{ Table 14: What data problems that have been experienced? } \\
\hline Country & $\begin{array}{c}\text { Incomplete } \\
\text { data }\end{array}$ & $\begin{array}{c}\text { Poorly } \\
\text { presented } \\
\text { data } \\
\end{array}$ & $\begin{array}{l}\text { Errors in } \\
\text { the data }\end{array}$ & $\begin{array}{c}\text { Lack of } \\
\text { transparency } \\
\text { in the data }\end{array}$ & $\begin{array}{c}\text { Failure to follow } \\
\text { the specified } \\
\text { guidelines }\end{array}$ & Other \\
\hline Australia & Yes & Yes & Yes & Yes & Yes & Yes (a) \\
\hline \multicolumn{7}{|l|}{ Belgium } \\
\hline France & Yes & Yes & Yes & Yes & Yes & Yes (b) \\
\hline \multicolumn{7}{|l|}{ Italy } \\
\hline Japan & No & No & No & No & No & No \\
\hline \multicolumn{7}{|c|}{ The Netherlands (c) } \\
\hline Portugal & Yes & Yes & Yes & Yes & No & \\
\hline Sweden & & Yes & No & & & \\
\hline Switzerland & $\mathrm{n} / \mathrm{a}$ & $\mathrm{n} / \mathrm{a}$ & $\mathrm{n} / \mathrm{a}$ & $\mathrm{n} / \mathrm{a}$ & $\mathrm{n} / \mathrm{a}$ & \\
\hline UK & Yes & Yes & Yes & & Yes & \\
\hline
\end{tabular}

a. Uncertainty in the estimates of comparative effectiveness, especially arising from errors of interpretation of results from various types of clinical studies. Other problems include uncertainty around cost estimates and errors in analysis of data (e.g., calculation errors).

b. Choice of the comparator by firms.

c. Not applicable, since pharmacoeconomic analyses have so far not been evaluated and outcomes are not yet applied in the reimbursement process.

n/a Not applicable

75. The biggest problem appears to be with the presentation of data by sponsors. In fairness to sponsors, it must be emphasised again that this is a new area for them and they are learning as they go. In addition, sponsors may be asked to report the same data in different formats for different countries which increases the cost of complying and reduces efficiencies. 
DELSA/ELSA/WD/HEA(2003)4

\section{RESULTS FROM PHARMACOECONOMIC ASSESSMENT}

76. This section of the report focuses on the volume of pharmacoeconomic assessments that have been completed and some of the results from those analyses.

\section{Examples of pharmacoeconomic assessment}

77. Before discussing the results of the survey in terms of pharmacoeconomic assessment, this paragraph intends to provide examples of pharmcoeconomic assessments for lay readers who would wish to understand what a pharmacoeconomic assessment is in a concrete way. However, it is not very easy to provide direct answers to this question. In many countries, examples of pharmacoeconomic assessments are not readily available to the general public, as many of these documents have been prepared by pharmaceutical companies and contain proprietary information that product sponsors wish to protect. The decisions made by public agencies based on information in the reports are publicly available, but the actual reports tend to be lengthy technical documents not of general interest. For example, decisions of the Australian PBAC are published on their website, but the pharmacoeconomic assessment report is not published. A link to this website is given below:

$$
\text { http://www.health.gov.au/pbs/listing/pbacrec/index.htm }
$$

78. In a few countries, pharmacoeconomic assessments are conducted directly by the relevant public agency and made public as part of the assessment process. This is, for example, the case for the reports produced by NICE in the UK (which include both health technologies and pharmaceutical treatments). An interested reader can find examples of these documents on the following website:

http://www.nice.org.uk/catta1.asp?c=153

\section{Number of assessments completed}

79. Answers to this question are difficult to compare because countries have implemented their programmes at different times and what is considered an "assessment" in one country may not be counted in another. This question was included in the survey to provide a rough indication of the level of activity. Counting the number of assessments also is difficult because in some instances the same product may receive more than one assessment. For example, in Australia, the same product would be evaluated separately for each indication. With these cautions in mind, the data in Table 15 shows the number of assessments ranged from 281 in Australia to seven in Portugal and the UK at the time of the study. Finally, when asked if assessment activities were currently focused on a particular therapeutic category, all countries responded negatively. 


\begin{tabular}{|c|c|c|c|c|c|}
\hline \multicolumn{6}{|c|}{ Table 15: Number of pharmacoeconomic assessments completed and appealed } \\
\hline Country & $\begin{array}{c}\text { Number of } \\
\text { products assessed }\end{array}$ & $\begin{array}{c}\% \text { denied } \\
\text { reimbursement }\end{array}$ & $\begin{array}{l}\% \text { denied a } \\
\text { price }\end{array}$ & $\begin{array}{c}\% \text { where the } \\
\text { denial was } \\
\text { reversed }\end{array}$ & $\begin{array}{c}\% \text { appealed by } \\
\text { product } \\
\text { sponsor }\end{array}$ \\
\hline Australia & 281 & & & & \\
\hline \multicolumn{6}{|l|}{ Belgium } \\
\hline \multicolumn{6}{|l|}{ France } \\
\hline Italy & $<10$ & $50 \%$ & & $50 \%$ & $100 \%$ \\
\hline Japan & 37 & 0 & $3 \%$ & 0 & \\
\hline \multicolumn{6}{|c|}{ The Netherlands } \\
\hline Portugal & 7 & 0 & 0 & 0 & 0 \\
\hline Sweden & 49 (a) & $1 / 49$ & 0 & 0 & 0 \\
\hline Switzerland & $\mathrm{n} / \mathrm{a}$ & & & & \\
\hline UK & 7 & 0 & $0(\mathrm{c})$ & 0 & $\mathrm{X}(\mathrm{c})$ \\
\hline
\end{tabular}

a. Number shown is for 1998 to 1999.

b. The 2500 assessments are from the 7333 drugs on the market for which reimbursement was granted on the basis of economic analysis.

c. There were appeals against aspects of the appraisal of taxanes for breast cancer and against the appraisal of beta interferon (still not complete at the time of the survey). None of the products reviewed received a recommendation against use - the decisions do not cover pricing or reimbursement.

80. In this part of the survey respondents were asked if their assessments were currently focused on a particular therapeutic category or class of drugs. This might be the strategy if, for example, a new class of drugs was marketed that was either very expensive or required special scrutiny because the benefits were only realised when used with very specific patient populations. Every respondent indicated they were not currently engaged in targeted assessments of this type.

\section{Contribution toward accomplishing programme objectives}

81. Not all countries have the same objectives so tabulating responses on accomplishments is difficult. For example, the UK did not answer this question because its objectives for NICE did not include the options provided. For those countries that did respond, respondents were most likely to indicate that the programme had improved the cost-effectiveness of prescribing. They were least likely to indicate that the programme had reduced the cost of prescription drugs. This latter finding is not surprising since the objective stated by most countries was to provide value-for-money rather than acting as a cost-containment mechanism.

82. When asked if they planned major changes in the operation of the pharmacoeconomic programme only a minority answered "yes". One of the affirmative responses was Belgium which is in the process of fully implementing its pharmacoeconomic assessment programme. The other affirmative response was from Japan which indicated there was interest in moving from cost-per-day calculations to a more comprehensive pharmacoeconomic assessment programme. (see Table 16). 


\begin{tabular}{|l|c|c|c|c|}
\hline \multicolumn{5}{|c|}{ Table 16: Accomplishment of goals set for pharmacoeconomic assessment } \\
\hline Country & $\begin{array}{c}\text { Reduced total } \\
\text { drug expenditure }\end{array}$ & $\begin{array}{c}\text { Reduced } \\
\text { unnecessary drug } \\
\text { use }\end{array}$ & $\begin{array}{c}\text { Improved the } \\
\text { cost-effectiveness } \\
\text { of prescribing }\end{array}$ & $\begin{array}{c}\text { Sensitized } \\
\text { drug firms to } \\
\text { the need for } \\
\text { effective drugs }\end{array}$ \\
\hline Australia & No & No & Yes & No \\
\hline Belgium & Yes & No & Yes & No \\
\hline France & No & Yes & No & No \\
\hline Italy & No & No & Yes & \\
\hline Japan & No & Yes & n/a & n/a \\
\hline Portugal & No & n/a & & \\
\hline Sweden & n/a & & & \\
\hline Switzerland (a) & & & & \\
\hline UK & &
\end{tabular}

a. Since studies are not usually required, this question does not apply.

n/a Not applicable

\section{Main obstacles to achieving objectives}

83. Table 17 shows that the biggest obstacle to obtaining improved results from pharmacoeconomic assessments was the scarcity of experts to do the assessments. The next most common problem was perceived to be inappropriate prescribing. This is a difficult problem to solve because it will require modification of prescriber behaviour which is not something intrinsic to pharmacoeconomic assessment. Given the magnitude of the perceived problem, the ability of pharmacoeconomic assessment to deliver savings is in doubt. If the programme objective is not cost containment then this may not be a problem. However, it is a problem if the programme objective is value-for-money since, by definition, value of the product is being reduced through inappropriate use. 


\begin{tabular}{|c|c|c|c|c|c|c|}
\hline \multicolumn{7}{|c|}{$\begin{array}{c}\text { Table 17: Which of the following are considered obstacles to obtaining improved results from } \\
\text { pharmacoeconomic assessment }\end{array}$} \\
\hline Country & A & B & $\mathrm{C}$ & $\mathrm{D}$ & $\mathrm{E}$ & $\mathrm{F}$ \\
\hline Australia & Yes & No (a) & No & Yes & Yes & No \\
\hline Belgium & No (b) & Yes (c) & & & & Yes \\
\hline \multicolumn{7}{|l|}{ France } \\
\hline Italy & No & No & No & No & No & Yes \\
\hline Japan & No & No & No & No & No & Yes \\
\hline The Netherlands (d) & No & No & & & Yes & Yes \\
\hline Portugal & No & No & No & No & Yes & Yes \\
\hline Sweden & No & Yes & No & Yes & Yes & No \\
\hline Switzerland & $\mathrm{n} / \mathrm{a}$ & $\mathrm{n} / \mathrm{a}$ & $\mathrm{n} / \mathrm{a}$ & $\mathrm{n} / \mathrm{a}$ & $\mathrm{n} / \mathrm{a}$ & $\mathrm{n} / \mathrm{a}$ \\
\hline UK & No & & No & No & & No \\
\hline
\end{tabular}

Definitions for column headings are as follows:

$\mathrm{A}=$ Problems with existing legal authorisation.

$\mathrm{B}=$ Inadequate public resources.

$\mathrm{C}=$ Lack of co-operation from pharmaceutical companies.

$\mathrm{D}=$ Inappropriate drug use by consumers.

$\mathrm{E}=$ Drugs prescribed inappropriately.

$\mathrm{F}=$ Not enough experts available to do the analyses.

\section{NOTES:}

a. The addition of further resources over the last 12 months is redressing these issues.

b. This is a move to change the old law in Parliament with respect to pharmacoeconomic evaluations.

c. Currently, the service is not available.

d. Answers indicate the issues which are expected to be obstacles. Don't know the answer to "C".

n/a Not applicable

\section{Interest in international cooperation}

84. All participating countries were asked what types of international co-operation would be beneficial for their efforts in the area of pharmacoeconomic assessment (see Tables 18 and 19). The most popular form of co-operation chosen by respondents was devising a way to facilitate communication among national assessment groups. Most of the countries suggested arranging periodic meetings to discuss assessment issues was a good form of co-operation. Some countries agreed strengthening the role of international agencies operating at the world level, creating mutually agreed guidelines for conducting assessments, and creating a standard format for sponsors to follow when submitting assessments to countries were good forms of co-operation. 


\begin{tabular}{|c|c|c|c|c|c|c|}
\hline \multicolumn{7}{|c|}{$\begin{array}{c}\text { Table 18: Types of international co-operation that would be beneficial for pharmacoeconom } \\
\text { assessment among all countries }\end{array}$} \\
\hline Country & $\mathrm{A}$ & B & C & $\mathrm{D}$ & $\mathrm{E}$ & $\mathrm{F}$ \\
\hline Australia & $\mathrm{X}$ & & & $\mathrm{X}$ & $\mathrm{X}$ & $\mathrm{X}$ \\
\hline Belgium & $X$ & $\mathrm{X}$ & $\mathrm{X}$ & $\mathrm{X}$ & $X$ & \\
\hline \multicolumn{7}{|l|}{ France } \\
\hline Italy & & & & $\mathrm{X}$ & & \\
\hline Japan & & & & & $X$ & \\
\hline The Netherlands & $\mathrm{X}$ & $\mathrm{X}$ & $\mathrm{X}$ & $\mathrm{X}$ & $X$ & \\
\hline Portugal & & & $\mathrm{X}$ & $\mathrm{X}$ & $\mathrm{X}$ & \\
\hline Sweden & & $\mathrm{X}$ & & & & \\
\hline \multicolumn{7}{|l|}{ Switzerland } \\
\hline UK & & & & $\mathrm{X}$ & $\mathrm{X}$ & \\
\hline
\end{tabular}

Definitions for column headings are as follows:

$\mathrm{A}=$ Strengthen the role of international agencies operating at a world level.

$\mathrm{B}=$ Create mutually agreed guidelines for conducting assessments.

$\mathrm{C}=$ Create a standard format for sponsors to follow when submitting assessments.

$\mathrm{D}=$ Arrange periodic meetings to discuss assessment issues.

$\mathrm{E}=$ Devise a way to facilitate communication among national assessment groups .

$\mathrm{F}=$ Other

Table 19: Types of international co-operation that would be beneficial for pharmacoeconomic

\begin{tabular}{|l|c|c|c|c|c|c|}
\hline \multicolumn{1}{|c|}{ Country } & $\mathrm{A}$ & $\mathrm{B}$ & $\mathrm{C}$ & $\mathrm{D}$ & $\mathrm{E}$ & $\mathrm{F}$ \\
\hline Belgium & Possible & $\mathrm{X}$ & $\mathrm{X}$ & $\mathrm{X}$ & $\mathrm{X}$ & \\
\hline Italy & & & & $\mathrm{X}$ & & \\
\hline The Netherlands & & $\mathrm{X}$ & $\mathrm{X}$ & $\mathrm{X}$ & $\mathrm{X}$ & \\
\hline Portugal & $\mathrm{X}$ & $\mathrm{X}$ & $\mathrm{X}$ & $\mathrm{X}$ & $\mathrm{X}$ & \\
\hline Sweden & & $\mathrm{X}$ & & & & \\
\hline Switzerland & & & & & & \\
\hline UK & & & & & & \\
\hline Totals & & & & & & \\
\hline
\end{tabular}

Definitions for column headings are as follows:

$\mathrm{A}=$ Strengthen the role of international agencies operating at the European level.

$\mathrm{B}=$ Create mutually agreed guidelines for conducting assessments.

$\mathrm{C}=$ Create a standard format for sponsors to follow when submitting assessments.

$\mathrm{D}=$ Arrange periodic meetings to discuss assessment issues.

$\mathrm{E}=$ Devise a way to facilitate communication among national assessment groups.

$\mathrm{F}=$ Other 
85. Separate questions were posed for all respondents and for European respondents because of the special considerations within the EU. As might be expected, the European respondents answered similarly for both questions. Many European countries are small and all include pharmaceuticals in their publiclyfunded programmes. Therefore, an increase of information sharing across European countries could be potentially beneficial.

\section{A REVIEW OF PHARMACOECONOMIC ASSESSMENT ACTIVITY IN THE UNITED STATES}

86. Because the US pharmaceutical market is split between a private sector and various government programmes, the US is not considered a single-payer market. There is no single national drug benefit programme (Medicare provides health insurance for the elderly, but does not include an outpatient drug benefit) so the absence of a single national pharmacoeconomic guideline is not surprising.

87. Recently, product manufacturers have realised the advantages of making economic claims for their products and have begun to generate pharmacoeconomic data with the intent of using it for product marketing. The FDA has reviewed these claims prior to product launch and made decisions on a case-bycase basis, rather than publishing a specific standard (Bonastia, 1994). In the absence of separate standards for demonstrating an economic benefit, the FDA has set the same standard for economic claims that it uses for safety and efficacy claims. An appreciation for pharmacoeconomic guideline activity in the US requires consideration of both the private and public sectors.

\section{Federal government activity}

88. Two federal government entities (the VA and the Department of Defense) currently make economic assessments of pharmaceuticals for use in their own pharmaceutical service programmes.

The Veterans Affairs Pharmacy Benefits Management Strategic Health Care Group (VAPBM) publishes treatment guidelines and drug class reviews. ${ }^{6}$ Each of these may contain opinions on the cost of therapy or, in the case of drug class reviews, recommendations on whether to admit a product to a formulary. However, the VA PBM has not published a set of guidelines used in their internally generated economic assessments.

The Department of Defense (DoD) Pharmacoeconomics Center (PEC) was founded to, "improve the clinical, economic, and humanistic outcomes of drug therapy in support of the readiness and managed healthcare missions of the Military Health System(MHS)." ${ }^{, 7}$ Activities of the DoD PEC include pharmacoeconomic analysis to support DoD formulary management, contracting activities, and clinical practice guideline development. These analyses are internally generated at the PEC. The PEC does not publish guidelines used for its assessments.

6. Information on the activities of the Veterans Affairs PBM is available from www.vapbm.org/PBM.

7. Information on activities of the Department of Defense Pharmacoeconomics Center is available from www.pec.ha.osd.mil. 


\section{Private sector activity}

89. The US market for healthcare services is characterised by a large private sector dominated by insurers and managed-care providers. Large insurers and managed-care organisations have begun to employ economic analysis of pharmaceuticals to assist them with their formulary decisions. Because this is a problem shared by many insurers the Academy of Managed Care Pharmacy (AMCP) has recently published guidelines for conducting formulary assessments that include an economic assessment. At this writing, the AMCP Format for Formulary Submissions was in use by managed-care organisations covering in excess of 100 million lives. ${ }^{8}$ Although not an official standard, the extent of coverage lends importance to the guidelines. The AMCP guidelines are intended to be a, “... template for pharmaceutical and medical device manufacturers to use to construct a formulary submission dossier designed to make the product evaluation process in formulary development more rational." ${ }^{\circ}$ While the format covers all aspects of formulary decision making the discussion here is limited to the economic component.

90. AMCP views the dossier format as a means for pharmaceutical manufacturers to justify the price of a new drug in terms of its value to the health plan. Methods of economic evaluation used by the product sponsor are not specified by the guidelines, but the methods chosen must be appropriate for demonstrating value. The guidelines do specify that the analysis orientation should be disease-based and not clinical-trial oriented. The guidelines permit a variety of analytic approaches including prospective studies piggybacked onto pivotal clinical trials, naturalistic comparative studies, retrospective studies, and modeling studies. The data provided must be broadly applicable for the health plan to which the dossier is submitted, and it must be sufficient for the health plan to judge the merit of the individual studies submitted in support of the request for formulary listing.

91. The guidelines anticipate that economic models will be provided. When offered as support for the product, they must evaluate the impact of the new product on costs as well as clinical and humanistic outcomes for the plan's population. As mentioned above, the model must be disease-based and consider all the relevant treatment pathways. Results from the model are expected to provide either cost/consequences tables or cost-effectiveness ratios. The comparator is expected to be appropriate, the clinical endpoints must be relevant, and there must be a sensitivity analysis of the pivotal estimates and assumptions. While the model is disease-based, the clinical and economic data are expected to be taken from clinical trials and modified to be realistic for the plan's population.

92. The AMCP Format for Formulary Submissions is very similar to the guidelines developed by Australia and CCOHTA, but AMCP does appear to offer more latitude on the selection of an economic evaluation method and the costs to include in the analysis. The AMCP guidelines note that major pharmaceutical manufacturers are already submitting outcomes modeling data as part of their submissions to national formularies.

8. Personal communication with Gene Reeder, PhD, AMCP President, April 30, 2002.

9. The AMCP format is available in print and on the AMCP web site at www.amcp.org. 


\section{CONCLUSIONS}

93. This section brings together some of the key findings, both from the literature review and from the survey of pharmacoeconomic assessment activities in eleven countries.

94. In the face of rapid pharmaceutical innovation and rising drug expenditure under public programmes, formal government requirements for pharmacoeconomic assessment and official pharmacoeconomic assessment agencies are spreading among OECD member countries. The first country to require pharmacoeconomic assessment in support of applications for listing of new pharmaceutical products under its schedule of publicly-funded pharmaceutical benefits was Australia in 1993. Judging by this survey, at least ten other OECD countries had followed Australia's lead by 2001 - if not always to the stage of making such assessments a formal requirement for listing.

95. A little under half of the countries in the survey reported using pharmacoeconomic assessment to establish the value-for-money of new pharmaceuticals. A few countries reported that they used it mainly for cost-containment purposes. That may have been because a number of countries in the study rely on other regulatory mechanisms for cost containment - such as global budgets or price controls. The literature suggests that the most frequent use of the assessments is for reimbursement decisions and the least frequent is for pricing decisions. In some instances, respondents noted that the assessments had the dual purposes of cost containment and determining value-for-money.

96. There were no reports from national assessment agencies about lack of co-operation from pharmaceutical companies in making the assessments. That may be surprising since the stakes for costeffectiveness decisions can be high. However, both pharmaceutical companies and governments will have an interest in establishing the economic case for new drugs. Interests will only diverge when drugs are shown to be less cost-effective than the government-established benchmark.

97. In the vast majority of the cases, the product sponsor did the initial assessment. That raises questions about the potential for bias in reaching results. Evidence of the need for caution was recently presented in a study by Friedberg and colleagues (see above) in which they did not find bias in industry sponsored drug studies, but a reduced likelihood that unfavourable results would be reported.

98. Many, if not all, assessment agencies stipulated certain criteria (guidelines) for conducting pharmacoeconomic assessments. However, there remained some flexibility in the assessment process such as selecting the type of analysis (such as cost-effectiveness analysis or cost-utility analysis), choosing the comparator, and including discounting where necessary. All countries required some form of sensitivity analysis. It has been pointed out in the literature that whereas the industry and the assessment agencies have different economic perspectives on reimbursement and pricing decisions, both are likely to share a common interest in harmonising reporting standards.

99. The survey revealed some common difficulties with the quality of assessments such as: inadequate data, poor presentation and capacity problems (a shortage of staff with the necessary skills). That suggests that further investment in skilled resources and further improvement in methods may be required. However, an eye must be kept on the costs of the activity both in terms of research effort and in terms of any additional delay it causes in reimbursement for, and therefore access to, new, cost-effective, pharmaceutical products under the programme in question. There is also the risk that pharmacoeconomic assessment may discourage beneficial pharmaceutical innovation - that is innovation which adds value compared with existing products. 
100. Is pharmacoeconomic assessment meeting its goals? The survey suggests that it is proving to be a useful decision-making tool for governments. A majority of countries that responded to the survey stated that it met its goals either for improving the cost-effectiveness of prescribing or for sensitising drug firms to the need for effective drugs. Only two countries said that it reduced total drug expenditure. That may or may not be a reassuring finding for the pharmaceutical industry. We do not know the counterfactual whether there might have been an even greater increase in drug expenditure in the absence of pharmacoeconomic assessment activities.

101. The main obstacle to improving the final impact of assessments seems to lie in the way that new drugs are prescribed following the approval for listing. That is presumably because many new drugs are soon used for medical indications beyond those established in the assessment which led to their marketing under the public programme. However, the survey was not designed to follow-up this issue.

102. One of the clearest messages from the survey is the enthusiasm that exists among the respondents for greater international co-operation among pharmacoeconomic assessment agencies. A large majority of the respondents voted in favour of periodic meetings to discuss assessment issues or to devise ways to facilitate communication among assessment groups. About one-third of the countries voted for standardised guidelines or formats for assessments. However, the demand, at least at this stage, seems to be more for inter-agency communication than for harmonisation of methods.

103. Judging by the rate at which the formal use of pharmacoeconomic assessment is spreading among OECD member countries, it is proving to be a useful decision-making tool for publicly-funded pharmaceutical benefit schemes as well as private benefit managers when they have the responsibility for reimbursing drugs.

104. The pharmaceutical industry expresses fear that the underlying purpose of pharmacoeconomic assessment is cost containment and that the imposition of a 'fourth hurdle' may stifle innovation. However, there is relatively little evidence from this survey that that is the case, or that overall drugs expenditure or its growth rate have been reduced as a result of pharmacoeconomic assessment activities (although, strictly, we do not know the counterfactual).

105. Formal pharmacoeconomic assessment is still a growing activity, with plenty of room to improve its quality. Meanwhile, it is an activity which is almost certainly subject to diminishing returns. The challenge is to find its optimum level - that level which balances its marginal benefits with its marginal costs. The benefits will include short-run gains in the cost-effectiveness of pharmaceutical consumption and, potentially, longer-term gains if the assessment process stimulates drug companies to reorient their research towards greater prospective added value. After a point, there are likely to be falling marginal returns to increased assessment activity. The costs will include assessment effort itself; any additional delay which assessments impose on the purchase of drugs which prove to be cost-effective; and any deterrence of useful innovation in future. After a point, there are likely to be rising marginal costs from increased assessment activity.

106. There is much interest, among the countries which have been surveyed here, in improved international communication across national pharmacoeconomic assessment agencies. Presumably it is perceived that there would be potential gains in quality and reductions in the cost of assessments from sharing technical knowledge and experience across countries. 


\section{ANNEX A: DEFINITIONS AND ABBREVIATIONS}

The definitions of certain technical terms used in the report are provided below. Definitions were drawn from a variety of sources, listed below.

Benchmark: A cost-effectiveness (or cost-utility) threshold or ratio, used by the pharmacoeconomic assessment agency as a standard for a public drug programme (perhaps implicitly). A new product whose cost-effectiveness is shown to exceed the benchmark would be more likely to be viewed favourably for reimbursement whereas a new product whose cost-effectiveness is shown to fall short of the benchmark would be less likely to be viewed favourably for reimbursement. For a fuller discussion of such benchmarks/thresholds see Towse et. al., 2002.

Cost-benefit analysis (CBA): An analytical technique that compares the net costs of a health care intervention with the net benefits, expressed in monetary units. A difficulty in the application of this method is valuing premature death or quality of life in monetary terms

Cost-effectiveness analysis (CEA): An analytical technique that compares the net monetary costs of a health care intervention with a measure of effectiveness (e.g., a clinical or quality of life outcome) resulting from the intervention. Costs are measured in monetary units and effectiveness is measured in natural units (e.g., years of life saved).

Cost-effectiveness threshold: see 'benchmark'.

Cost-of-illness analysis: A study identifying and evaluating the financial burden of a disease or medical condition from a particular perspective (e.g., societal, payer, patient, etc.). Also known as a cost-of-disease or burden-of-illness analysis.

Cost-minimisation (CMA): A form of cost-effectiveness analysis in which it is assumed (provided there is adequate justification) that the interventions being compared yield medically equivalent results. Since results are assumed to be medically equivalent, the analysis is reduced to a comparison of the costs of the interventions. A comparison of generically equivalent drugs is a classic example.

Cost-utility analysis (CUA): A form of cost-effectiveness analysis in which utility values or weights are assigned to different kinds of health outcomes, reflecting the relative importance of the different outcomes to people. Aggregated or composite outcomes are generally expressed in units such as quality-adjusted lifeyears (QALY). Costs are measured in monetary units.

Direct medical cost: Costs associated directly with a medical condition or health care intervention. These include the costs of services and products used in the care of patients, such as hospital stays, physician and other health professional encounters, emergency room visits, medical equipment, etc.

Direct non-medical cost: The cost of providing patients all non-medical assistance such as food, lodging and transportation when they are related to the illness or health care intervention but are not direct medical costs.

Discounting: A procedure used in economic analysis to reduce to "present values" those costs and benefits that will occur in future years by applying the inverse of a rate of interest. Discounting is based both on the premise that individuals prefer to receive benefits (e.g., revenue) today rather than in the future and on the observation that resources invested today can earn a positive rate of return over time. 
Efficacy: The degree to which a therapeutic outcome is achieved in a patient population under rigorously controlled and monitored circumstances, such as randomised controlled clinical trials. Efficacy is generally evaluated in a controlled trial that compares an experimental therapy to a control group (sometimes a placebo), and is the standard for drug approval by regulatory authorities.

Effectiveness: The degree to which a therapeutic outcome from a medical intervention is achieved in a general population under actual or average conditions of use. Alternatively, the probability of benefit to an individual in a defined population from a medical technology applied for a given medical condition under average or actual conditions of use.

Health technology assessment: Economic evaluation of the properties and effects of a technology (e.g., a drug, device or diagnostic test), typically before the technology has come into general use, for coverage or reimbursement and coverage purposes. Pharmacoeconomic assessment refers to a specific type of health technology assessment in which the technology is a drug.

Indirect cost: Cost of lost or reduced productivity resulting from morbidity or premature mortality due to a medical condition or treatment, usually expressed in monetary terms.

Opportunity cost: The value of foregone benefits because a health care resource is not available for its best alternative use. The value of the foregone benefit is the opportunity cost. For example, if resources are committed to running a hospital, those resources are not available for another purpose.

Outcome: Any change in health status brought about by a preventive or therapeutic health care intervention. Generally, a key object of measurement in a pharmacoeconomic analysis. Outcomes can be beneficial or detrimental.

Pharmacoeconomic assessment: Economic assessment of the relative benefits and costs of a drug compared with another (best alternative) drug, treatment or placebo.

Quality-adjusted life year (QALY): The most commonly used unit to express health outcome. A patientreported health utility measure combining quality and quantity of life. There are various methods for measuring QALYs.

Quality of Life (QOL): A consequence of the use of a health care intervention that affects a patient's physical functioning (including extent and severity of symptoms and physical capacity), social functioning (including role function or employment), psychological and emotional functioning. Sometimes includes evaluations of a patient's functional status.

Safety: The presence or absence of adverse events associated with the use of a health technology.

Sensitivity analysis: The standard method to manage uncertainty within a health technology assessment or economic evaluation. It involves changing the value of one (a one-way analysis) or more variables (multiway analysis) across the range of plausible alternative values while holding other variables constant, and assessing the effect on the overall decision. If the sensitivity analysis does not materially change the decision, the conclusions are regarded as robust.

Time horizon: The time period over which patients will be followed and their healthcare utilisation and outcomes tracked. This becomes the relevant time period over which to make the economic assessment of the intervention. Also called "analytical horizon". 


\section{REFERENCES}

ARISTIDES, M and A. MITCHELL (1994)

"Applying the Australian guidelines for the reimbursement of pharmaceuticals", PharmacoEconommics 6:3, pp. 196-201.

BONASTIA, C.J. (1994)

"What is the FDA's position on pharmacoeconomic data in promotion?", Outcomes Measurement Management 5:6, pp. 1-2 (1994).

BOOTMAN, J.L., R.J. TOWNSEND and W.F. McGHAN (1996)

Principles of pharmacoeconomics, Second edition, Cincinnati: Harvey Whitney Books.

DRUMMOND, M. (1992)

"Australian guidelines for cost-effectiveness studies of pharmaceuticals: The thin end of the boomerang?", PharmacoEconomics 1:1 (Supplement 1), pp. 61-69.

DRUMMOND, M. et. al.(1993)

"Economic evaluation of pharmaceuticals: a European perspective", PharmacoEconomics 4:1, pp. 173-186.

DRUMMOND, M. (1994a)

"The emerging government requirement for economic evaluation of pharmaceuticals",

PharmacoEconomics 6:4 (Supplement 1), pp. 42-50.

DRUMMOND, M. (1994b)

"Guidelines for pharmacoeconomic studies: The way forward", PharmacoEconomics 6:6, pp. 493497.

DRUMMOND, M.F., G.L. STODDART, and G.W. TORRANCE (1991)

Methods for the economic evaluation of health care programmes, Oxford: Oxford University Press.

DRUMMOND, M., et. al. (1999)

"Current trends in the use of pharmacoeconomic and outcomes research in Europe", Value in Health 2:5, pp. 323-332.

DETSKY, A. (1993)

"Guidelines for economic analysis of pharmaceutical products: A draft document for Ontario and Canada", PharmacoEconomics 3:5, pp. 354-361.

FRIEDBERG, M. et. al. (1999)

"Evaluation of conflict of interest in economic analyses of new drugs used in oncology", JAMA 282, pp. 1453-57.

GOETGHEBEUR, M.M. and D. RINDRESS (1999)

"Towards a European consensus on conducting and reporting health economic evaluations-A report from the ISPOR inaugural European conference", Value in Health 2:4, pp. 281-287. 
GROBLER, M.P., et al. (1996)

"Industry comment on the 1995 revised Australian pharmacoeconomic guidelines", PharmacoEconomics 9:4, pp. 353-356.

HAILEY, D. (1997)

"Australian economic evaluation and government decisions on pharmaceuticals, compared to assessment of other health technologies", Social Science \& Medicine 45:4, pp. 563-581.

HENRY, D. (1992)

"Economic Analysis as an aid to subsidisation decisions: The development of Australian guidelines for pharmaceuticals", PharmacoEconomics 1:1, pp. 54-67.

HILLMAN, A., et. al. (1991)

"Avoiding bias in the conduct and reporting of cost-effectiveness research sponsored by pharmaceutical companies", New England Journal of Medicine 324:19, pp. 1362-65.

HISASHIGE, A. (1997)

"Healthcare technology assessment and the challenge to pharmacoeconomics in Japan", Pharmacoeconomics 11:4, pp. 319-333.

P. JACOBS, J., J. BACHYNSKY, and J. BALADI (1995)

"A comparative review of pharmacoeconomic guidelines", PharmacoEconomics 8:3, pp. 182-189.

JACOBZONE, S. (2000)

"Pharmaceutical policies in OECD countries: Reconciling social and industrial goals", OECD Labour Market and Social Policy Occasional Papers No. 40.

JOHANNESSON, M. (1992)

"The Australian guidelines for subsidization of pharmaceuticals: The road to cost-effective drug prescribing?", PharmacoEconomics 2:5, pp. 355-362.

KIELHORN, A. and J-M GRAF von der SCHULENBURG (2000)

The Health Economics Handbook, Second edition, Tattenhall: Adis International.

LANGLEY, P.C. (1993)

"The role of pharmacoeconomic guidelines for formulary approval: The Australian experience", Clinical Therapeutics 15:6, pp. 1154-1176.

LANGLEY, P.C. (1996)

"The November 1995 revised Australian guidelines for the economic evaluation of M.P. Grobler, et al. Industry comment on the 1995 revised Australian pharmacoeconomic guidelines",

PharmacoEconomics 9:4, pp. 353-356.

MULLINS, C.D. and S. OGILVIE (1998)

"Emerging Standardization in Pharmacoeconomics", Clinical Therapeutics 20:6, pp. 1194-1202.

PASHOS, C.L., E.G. KLEIN and L.A. WANKE (editors) (1998)

ISPOR Lexicon, First edition, Princeton: International Society for Pharmacoeconomics and Outcomes Research.

PHARMACEUTICAL MANAGEMENT AGENCY LIMITED (Pharmac) (1993)

Operating policies and procedures. Wellington, New Zealand.

TOWSE, A., C. PRITCHARD and N. DEVLIN (2002)

Cost-effectiveness thresholds, economic and ethical issues; Kings Fund/OHE, London. 


\section{OECD HEALTH WORKING PAPERS}

Most recent releases are:

No. 1 PHARMACEUTICAL USE AND EXPENDITURE FOR CARDIOVASCULAR DISEASE AND STROKE: A STUDY OF 12 OECD COUNTRIES (2003) Michael Dickson and Stéphane Jacobzone

No. 2 INVESTMENT IN POPULATION HEALTH IN FIVE OECD COUNTRIES (2003) Jan Bennet

No. 3 OECD STUDY OF CROSS-NATIONAL DIFFERENCES IN THE TREATMENT, COSTS AND OUTCOMES OF ISCHAEMIC HEART DISEASE (2003) Pierre Moise, Stéphane Jacobzone and the ARD-IHD Experts Group

Other series of working papers available from the OECD include:

\section{OECD SOCIAL, EMPLOYMENT AND MIGRATION WORKING PAPERS}

Most recent releases are:

No. 1 CAREER INTERRUPTIONS DUE TO PARENTAL LEAVE: A COMPARATIVE STUDY OF DENMARK AND SWEDEN (2003) Elina Pylkkänen and Nina Smith

No. 2 THE DETERMINANTS OF CHILD LABOUR: THEORY AND EVIDENCE (2003) Drusilla K. Brown, Alan V. Deardorff and Robert M. Stern

No. 3 LE TRAVAIL DES ENFANTS EN AMÉRIQUE LATINE (2003) Pierre-Emmanuel Couralet

No. 4 CHILD LABOUR IN AFRICA (2003) Sonia Bhalotra

\section{LABOUR MARKET AND SOCIAL POLICY OCCASIONAL PAPERS}

This series has now been replaced by two separate series: OECD HEALTH WORKING PAPERS and OECD SOCIAL, EMPLOYMENT AND MIGRATION WORKING PAPERS, available on the OECD website.

No. 63 THE EVOLVING RETIREMENT INCOME PACKAGE: TRENDS IN ADEQUACY AND EQUALITY IN NINE OECD COUNTRIES (2002) Atsuhiro Yamada

No. 62 THE RELATIONSHIP BETWEEN PERSONAL, FAMILY, RESOURCE AND WORK FACTORS AND MATERNAL EMPLOYMENT IN AUSTRALIA (2002) Edith Gray and Peter McDonald

No. 61 LOW FERTILITY AND LABOUR FORCE PARTICIPATION OF ITALIAN WOMEN: EVIDENCE AND INTERPRETATIONS (2002) Daniela Del Boca

No. 60 GETTING OLDER, GETTING POORER, A STUDY OF THE EARNINGS, PENSIONS, ASSETS AND LIVING ARRANGEMENTS OF OLDER PEOPLE IN NINE COUNTRIES (2002) Bernard Casey and Atsuhiro Yamada

No. 59 POSTPONEMENT OF MATERNITY AND THE DURATION OF TIME SPENT AT HOME AFTER FIRST BIRTH: PANEL DATA ANALYSES COMPARING GERMANY, GREAT BRITAIN, THE NETHERLANDS AND SWEDEN (2002) Siv S. Gustafsson, Eiko Kenjoh and Cécile M.M.P. Wetzels

No. 58 SOCIAL ASSISTANCE IN GERMANY (2003) Willem Adema, Donald Gray and Sigrun Kahl

No. 57 IMPROVING THE PERFORMANCE OF HEALTH CARE SYSTEMS: FROM MEASURES TO ACTION (2001) Zynep Or

No. 56 AN ASSESSMENT OF THE PERFORMANCE OF THE JAPANESE HEALTH CARE SYSTEM (2001) Hyoung-Sun Jeong and Jeremy Hurst

Recent available working papers can be found on the OECD website: www.oecd.org. 
DELSA/ELSA/WD/HEA(2003)4

\section{RECENT RELATED OECD PUBLICATIONS:}

TRANSFORMING DISABILITY INTO ABILITY: Policies to Promote Work and Income Security for Disabled People (2003)

SOCIETY AT A GLANCE (2002)

TOWARDS ASIA'S SUSTAINABLE DEVELOPMENT - The Role of Social Protection (2002)

MEASURING UP: IMPROVING HEALTH SYSTEMS PERFORMANCE IN OECD COUNTRIES (2002)

BENEFITS AND WAGES - OECD Indicators (2002)

KNOWLEDGE AND SKILLS FOR LIFE: First Results from PISA 2000 (2001)

AGEING AND INCOME: Financial Resources and Retirement in 9 OECD Countries (2001)

HEALTH AT A GLANCE (2001)

SOCIETY AT A GLANCE: OECD Social Indicators (2001)

INNOVATIONS IN LABOUR MARKET POLICIES: The Australian Way (2001)

OECD EMPLOYMENT OUTLOOK July 2002 (published annually)

LABOUR MARKET POLICIES AND THE PUBLIC EMPLOYMENT SERVICE (Prague Conference) (2001)

TRENDS IN INTERNATIONAL MIGRATION: SOPEMI 2000 Edition (2001)

OECD HEALTH DATA (2002)

available in English, French, Spanish and German on CD-ROM (Windows 95, 98, 2000, NT or Me)

REFORMS FOR AN AGEING SOCIETY (2000)

PUSHING AHEAD WITH REFORM IN KOREA: Labour Market And Social Safety-Net Policies (2000)

A SYSTEM OF HEALTH ACCOUNTS (2000)

OECD ECONOMIC STUDIES No. 31, 2000/2 (Special issue on “Making Work Pay") (2000)

POLICIES TOWARDS FULL EMPLOYMENT (OECD Proceedings) (2000)

LABOUR MIGRATION AND THE RECENT FINANCIAL CRISIS IN ASIA:

(OECD Conference Proceedings) (2000)

OECD SOCIAL EXPENDITURE DATABASE, 1980-1998 (2001)

Third edition - Available in English and French on CD-ROM

For a full list, consult the OECD On-Line Bookstore at www.oecd.org, or write for a free written catalogue to the following address:

OECD Publications Service

2, rue André-Pascal, 75775 PARIS CEDEX 16

or to the OECD Distributor in your country 